\title{
El retorno del conflicto \\ Elecciones y polarización política en México
}

\author{
Alberto Aziz Nassif
}

El pacto de la transición, que era para el respeto al voto y la competencia equitativa, tuvo varios ingredientes que lo lastimaron de forma importante durante la sucesión presidencial del 2006: la autonomía del Instituto Federal Electoral quedó comprometida con la renovación de sus consejeros; la práctica de exclusión por parte del presidente de la República y la intervención ilegal de grupos empresariales, destruyeron la equidad de la contienda; el modelo de financiamiento público excesivo y acceso a los medios masivos generaron la campaña sucia más costosa y prolongada que se haya realizado en el país. Todas estas piezas armaron un conflicto que trastocó de manera importante la incipiente y frágil democracia mexicana.

PALABRAS CLAVE: elecciones presidenciales, campañas políticas, democracia, organismos electorales, financiamiento público, conflicto

The pact of transition, intended to ensure the legal scrutiny of the ballots and to guarantee a fair electoral competition, was severely damaged during the 2006 presidential election by several actions: the autonomy of the Federal Electoral Institute was compromised by the replacement of its counselors; the excluding practices of the President and the illegal intervention of businessmen associations destroyed the possibility of having a fair election; a campaign financing model that used excessive public funds and an unequal access to the media, generated the longest and most expensive slander campaign in the country's history. All these elements contributed to the emergence of a conflict that has affected the incipient and fragile Mexican democracy.

KEYWORDS: presidential elections, political campaigns, democracy, electoral institutions, public financing, conflict

ALBERTO AZIZ NASSIF: Centro de Investigaciones y Estudios Superiores en Antropología Social, México-Distrito Federal aziz@ciesas.edu.mx 
Los diseños institucionales de las democracias tienen poco que ver con el azar. Menos aún cuando se trata de establecer un sistema electoral, probablemente la institución más determinante en el corto plazo y con seguridad la más manipulable.

José Ramón Montero e Ignacio Lago

\section{INTRODUCCIÓN}

$\mathrm{D}$ os meses después de haber dejado el cargo de presidente, durante una conferencia en Washington, Vicente Fox afirmó: "[con el desafuero de López Obrador] tuve que retirarme y perdí. Pero 18 meses después me desquité cuando ganó mi candidato" ${ }^{1}$. Estas palabras son una síntesis del conflicto que se presentó durante la sucesión presidencial de 2006 en México. El reconocimiento de apuestas personales y políticas del presidente de la República expresan que hubo una manipulación — quizá un rompimiento— del pacto político que hizo posible la transición democrática, acuerdo que quedó expresado en las reglas e instituciones que se crearon en 1996 para cuidar y respetar el voto.

El pacto de la transición, que era para el respeto al voto, tuvo varios ingredientes que lo lastimaron de forma importante durante la sucesión presidencial de 2006: la autonomía del Instituto Federal Electoral quedó comprometida con la renovación de sus consejeros - electos a fines de 2003-, acción que representó el regreso de las cuotas partidistas; la práctica de exclusión por parte del presidente de la República destruyó la equidad de la contienda, y se sumó a otras intervenciones violatorias de la legalidad, como la de los grupos empresariales que hicieron campaña por el candidato del partido gobernante; el atrofiado modelo de financiamiento público excesivo y de acceso a los medios masivos generó la campaña sucia más costosa y prolongada que se haya realizado en el país. Todas estas piezas armaron un conflicto que trastocó de manera importante la incipiente y frágil democracia mexicana.

Para analizar estos supuestos desarrollamos siete par-

${ }^{1}$ El Universal, 13 de febrero de 2007. tes: primero vemos las reglas del juego y los ciclos electorales para entender en qué tipo de cancha se llevó a cabo este complicado partido. Enseguida hacemos un seguimiento de las piezas que construyeron la elección, las precampañas, la campaña y los gastos en medios masivos. Con estas partes tratamos de responder a la pregunta sobre qué era lo que estaba en juego con esta elección, cuáles eran los proyectos en disputa. Luego entramos a ver cómo quedaron los votos y qué modificaciones hubo en la geografía electoral. En las siguientes partes nos dedicamos a analizar la crisis poselectoral, el comportamiento de los organismos electorales y el dictamen de la elección. Al final puntualizamos algunas conclusiones que tratan de responder a la pregunta por el futuro después de este complejo regreso al conflicto electoral.

La democracia mexicana tiene poco tiempo de haber iniciado como un proceso de alternancia política y competencia partidista. Su desarrollo tuvo como base de sustento una serie de pactos electorales, cuyo objetivo principal fue garantizar el desarrollo de derechos mínimos, como el ejercicio del voto ciudadano, condiciones de equidad en la competencia, y la formación de gobiernos con base en la expresión de los sufragios. En este conjunto también se han creado en México ciertas garantías para contar con espacios para que los actores políticos y los ciudadanos puedan organizar el conjunto de derechos y libertades que construyen ciudadanía. Esta última parte es todavía más una aspiración que una realidad.

Entre 1977 y 1996 el país se hizo de un conjunto de reglas del juego electoral, de reformas y elecciones que, como un laboratorio permanente de ensayo y error, construyó el complejo entramado que hoy forma lo que podemos denominar como las instituciones de la democracia electoral. Hay que decirlo: el trayecto se hizo en contra de la adversidad, al ritmo de dos procesos que se vincularon de manera ineludible: la caída de un sistema de partido hegemónico, que luego tuvo un carácter dominante y llegó finalmente a un régimen de alta competencia sobre la base de una representación mixta, con dominante mayoritaria y con tres grandes partidos nacionales. El otro factor fue el crecimiento de una sociedad que se diversificó, se volvió plural y de forma permanente demandó un sistema confiable y equitativo de competencia. 


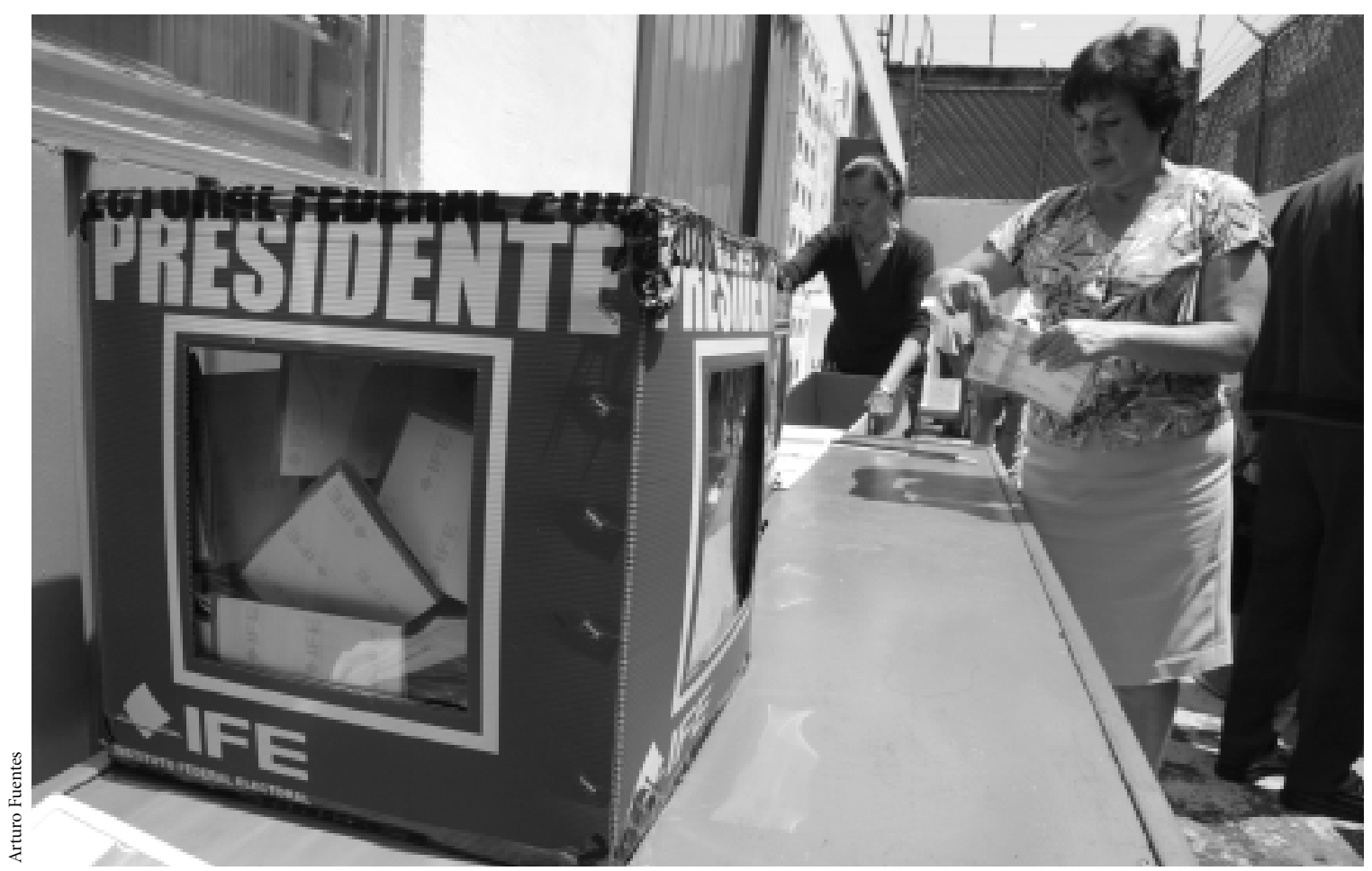

Proceso electoral de 2006.

En los antecedentes más remotos de este recorrido podemos establecer que en la evolución del fenómeno denominado durante años como transición a la democracia hubo momentos significativos, piezas estratégicas que expresan la formación del perfil de nuestra incipiente democracia. Son muchos los factores que nos pueden explicar la dinámica de cambios e inercias que hoy conforman lo que fueron las elecciones presidenciales de 2006.

Sin la pretensión de viajar en el túnel del tiempo, podemos anotar que hay procesos que marcaron la memoria, las reglas y las prácticas de esta incipiente democracia electoral. El corte puede empezar con lo que representó la sucesión presidencial de 1988, no sólo porque casi veinte años después sigue como un punto de referencia negativo que, obviamente, contrasta con lo que ha sucedido en México en las últimas dos décadas. En 1988 surge el sistema de los tres grandes partidos nacionales que le han dado identidad a la lucha electoral. El conflicto electoral de 1988 responde, entre otras cosas, a un sistema político y electoral que no estaba diseñado para procesar unas elecciones plurales y competidas, que fueron el fenómeno que dejó la ruptura cardenista y el desempeño de los partidos políticos agrupados en el Frente Democrático Nacional.

Seis años después, en 1994, presenciamos una sucesión caracterizada por la crisis que desencadenó el levantamiento zapatista y el dramatismo que trajo consigo el asesinato de Luis Donaldo Colosio como contexto y contenido de una campaña cuya característica central fue el voto del miedo. Las elecciones de 1994 tuvieron un conflicto más acotado electoralmente, en el cual uno de los problemas más relevantes fue, sin duda, el de las condiciones inequitativas en la competencia entre los partidos de oposición y el partido gobernante. A pesar de que las reglas habían cambiado por las tres reformas de ese sexenio - lo que creó una base institucional diferente-, no se tocaron los núcleos duros de la inequidad y el control gubernamental de las elecciones. 
En el año 2000, casi como una excepción, no hubo conflicto electoral. Las nuevas reglas de la reforma de 1996 se combinaron con un desempeño eficiente de los organismos electorales. El hecho de haberse tratado de una elección plebiscitaria, entre más de lo mismo o una alternancia presidencial, simplificó las opciones del voto y quizá fue el factor que permitió una ventaja suficiente entre los dos punteros. Además, se combinaron otros elementos de un círculo virtuoso, como la presencia discreta del presidente de la República durante la campaña y el reconocimiento del triunfo opositor, lo cual se sumó a la aceptación de la derrota por parte del perdedor. Estos factores despejaron la posibilidad de un conflicto. De hecho, esa elección pasó al registro histórico como la primera de un régimen democrático.

El planteamiento de este trabajo es que, un sexenio después, muchas cosas cambiaron para hacer de las elecciones de 2006 un proceso inversamente proporcional al del año 2000, conflictivo y polarizante, que pareció hacer que México regresara a los tiempos de desconfianza, del discurso del fraude y de la protesta callejera. Aparecieron de nuevo los signos de la adversidad en el escenario electoral. Para explicar esta inversión tomaremos en cuenta los siguientes factores:

a) La sucesión presidencial de 2006 fue una mezcla explosiva, un círculo perverso que llevó a confirmar que el sistema electoral, sus reglas y prácticas, no estaban diseñados para procesar una elección tan cerrada como la que tuvo el país el 2 de julio de ese año. La competencia estrecha y polarizante fracturó las fortalezas que se habían construido en los años anteriores y puso a prueba a todo el entramado institucional, cuyos resultados dejaron muy lastimados los cimientos del sistema electoral.

b) Se pensó, de manera equivocada, que lo ganado en términos de transparencia, equidad y certeza en sistema electoral que había sido exitoso relativamente en dos elecciones intermedias - 1997 y 2003- y en la sucesión presidencial del año 2000 estaba blindado y no era posible revertirlo. Sin embargo, los acontecimientos de 2006 mostraron lo contrario.

c) Las condiciones de la competencia volvieron a plan- tear un proceso plebiscitario, pero mucho más complejo que el de seis años antes. En esta ocasión se puso en juego, por lo menos en partes importantes del imaginario social, que no se trataba de una simple opción entre cambio y continuidad, entre dos candidatos o dos partidos políticos, sino que se trataba de una redefinición profunda del modelo de desarrollo, por lo cual la decisión no era sólo por un sexenio, sino por un periodo de tiempo mucho mayor.

d) La parte problemática de las reglas del juego —el financiamiento público de los partidos y el esquema de acceso a los medios para las campañas electorales (que ya habían sido conflictivos en los dos procesos anteriores, 2000 y 2003) — se potenció y produjo una campaña sucia de proporciones nunca antes vista en México. Esta situación formó un clima de alta polarización social y crispación política, que llegó a tener expresiones regionales e identidades clasistas.

\section{REGLASY CICLOS ELECTORALES}

El proceso electoral de 2006 mostró el agotamiento de la última reforma electoral que se hizo en 1996, durante el sexenio de Ernesto Zedillo. Las reglas del juego que se crearon en 1996 cumplieron un ciclo virtuoso en su diseño institucional, que se materializó en la autonomía de los organismos electorales, un proceso que se acercó bastante a una ciudadanización; en las condiciones de equidad en la competencia, mediante el financiamiento público y el acceso a los medios masivos de todos los partidos políticos con registro; en un sistema de medios de impugnación que posibilitó la resolución de los conflictos por un organismo jurisdiccional, el Tribunal Electoral del Poder Judicial de la Federación (TEPJF), independiente del mismo Instituto Federal Electoral (IFE). Con un diseño de autonomía y un desempeño institucional eficiente y adecuado, los organismos electorales lograron conducir la pluralidad política del sistema político y, al mismo tiempo, construir confianza para una formación legítima de los gobiernos.

A partir del año 2000 se inició, junto a las condiciones de confianza institucional, un ciclo perverso de incenti- 
vos, en el cual las mismas reglas que habían posibilitado la alternancia y logrado institucionalizar la competencia partidista provocaron el surgimiento de conflictos crecientes:

- El modelo de financiamiento público dejó de ser sólo la ruta para que hubiera equidad, y se convirtió en un lastre costoso; el dinero gastado en las elecciones, con sus múltiples candados para resolver la desconfianza y la cultura del fraude, empezó a multiplicarse sin que la calidad de los procesos o el nivel del debate político tuvieran una mejoría sensible. Sólo hay que recordar que los niveles de abstención crecieron en todos los procesos electorales posteriores al año 2000; en los comicios de 2003 prácticamente seis de cada diez ciudadanos no votaron, aunque los costos siguieron en aumento (Aziz, 2005).

- El esquema de acceso a los medios masivos también fue otra pieza que dejó de tener las virtudes iniciales y acentuó el perfil mediático de las campañas. Además de los tiempos que se reparten por parte del IFE, los partidos tienen el recurso de contratar y gastar lo que quieran en medios masivos, siempre que se sujeten a los topes de campaña. Pero el inconveniente con el modelo es que genera dos problemas: uno de déficit financiero permanente en los partidos, lo cual los lleva a meter recursos ilegales a las campañas, como sucedió con los paradigmáticos casos de Amigos de Fox y Pemexgate2 (no se trata de un problema mexicano, sino de un modelo más amplio que afecta a los partidos y a los sistemas electorales en muchos países); el otro problema es un déficit en los mecanismos de fiscalización de la autoridad y en la debilidad de los instrumentos para sancionar.

- El otro proceso conflictivo fue la reversión que empezaron a tener los organismos electorales en su carácter de ciudadanización ${ }^{3}$. Cuando a los partidos se les retiró el voto de las decisiones electorales, además de que

\footnotetext{
${ }^{2}$ Los dos casos de violación a los gastos de financiamiento permitidos en la campaña del año 2000 .

${ }^{3}$ Hay que tomar en cuenta que los nombramientos de toda estructura en el IFE se dan en "cascada" porque los consejeros electorales eligen a los consejeros locales y éstos a los consejeros distritales, y muchos de los participantes en las elecciones de 2000 y 2003 ya no repitieron en 2006.
}

el gobierno federal dejó de ser parte de la organización de los comicios, el modelo de autonomía de los organismos que cumplían funciones de Estado fue un diseño adecuado para revertir la desconfianza en las elecciones. Sin embargo, más se tardó la sociedad en empezar a asimilar el proceso que los partidos en regresar por la puerta trasera para volver a partidizar los nombramientos. Como sucedió a finales de octubre de 2003, cuando se renovó el grupo de consejeros electorales del IFE, y el Partido de Acción Nacional (PAN) y el Partido Revolucionario Institucional (PRI) se dividieron por cuotas los nombramientos, decisión estratégica negativa con la que se inició la preparación para las elecciones de 2006.

Como si el manto de confianza que se generó entre 1996 y 2003 fuera suficiente para enfrentar el proceso electoral de 2006, los partidos y sus fracciones parlamentarias - incluso los mismos candidatos a la presidenciasistemáticamente fueron incapaces de cambiar las reglas del juego, darle a la sucesión presidencial un nuevo perfil y la posibilidad de enfrentar los problemas anunciados con mejores instrumentos.

Una reforma electoral se planteaba ya en varios escenarios y con distintos alcances. Las elecciones de 2006 se anunciaban como una competencia muy cerrada entre los tres principales partidos. Una posibilidad era, por supuesto, no mover nada en la lógica de no correr ningún riesgo. Desde esta perspectiva, un escenario es que no hubiera reforma. En el caso de que sí se lograra algún tipo de consenso, la reforma podía ser gradual e ir desde un cambio para cubrir el expediente, con un alcance completamente menor - que no resolviera ninguno de los problemas importantes del actual modelo electoral, pero que sí tocara algunos temas como el de mayor capacidad de fiscalización al organismo electoral, incluso que respondiera a algunas demandas poco riesgosas, como las cuotas de género para las candidaturas- Por cierto, éste era uno de los temas que con mayor insistencia se proponía en los proyectos de reformas electoral en los estados del país.

Con una reforma menor no se tocaría el tema de los medios masivos, en el cual los partidos habían sido particularmente resistentes. Uno de los pendientes que te- 


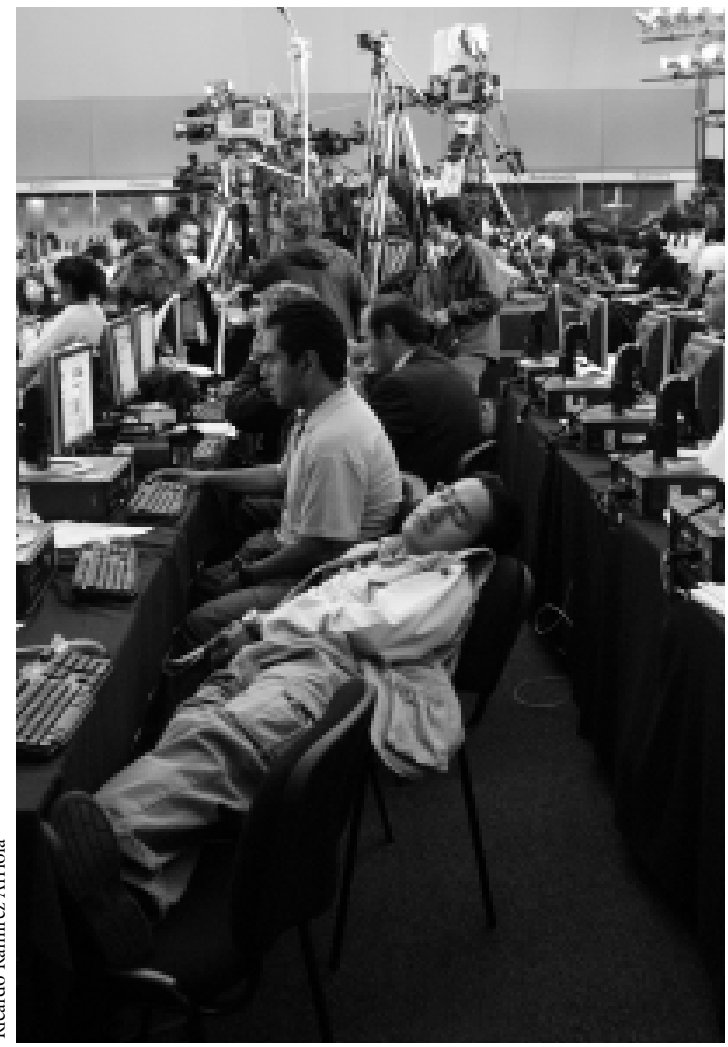

En la espera del conteo, megasala del IFE, 6 de julio de 2006.

nía más posibilidades de entrar en la agenda de reforma era el voto de los mexicanos en el extranjero, proyecto que salió con alcances amplios de la cámara de diputados, pero al que los senadores le hicieron fuertes ajustes para dejarlo en un simple voto por correo.

La agenda de una reforma electoral amplia cubría una gran cantidad de temas: desde el género en las candidaturas, la composición del poder legislativo con una reducción en el número de legisladores y un cambio en las proporciones que existen entre mayoría relativa y representación proporcional; pasaría por una redefinición de los montos y mecanismos del esquema de financiamiento público, que ha crecido por el multiplicador del número de partidos con registro. También tendría que tocar el dinero público de los partidos y cambiar el acceso a los medios para generar otro modelo de campañas, en el cual una posibilidad consistiría en que fuera sólo el organismo electoral el que hiciera el reparto del tiempo en radio y televisión, con lo cual se cortaría la principal salida de recursos partidistas, que es la contratación directa entre partido y medio. Ésta era, sin duda, una reforma muy importante, pero sus posibilidades de salir adelante eran muy escasas.

Frente a los escenarios de reforma, la posibilidad más alta era que, de acuerdo con el cálculo estratégico de los partidos para 2006, no se moviera nada que representara una disminución de recursos económicos - dinero y más dinero- para estar en la televisión la mayor cantidad de tiempo posible.

El 30 de junio de 2005 fue la fecha límite para cualquier reforma que se quisiera hacer en materia electoral para las elecciones de 2006, una reforma que pudiera enfrentar el círculo vicioso de los problemas que señalamos antes y que afectan de forma importante el desempeño de la incipiente democracia mexicana ${ }^{4}$.

Por la falta de una decisión reformadora, a pesar de los múltiples esfuerzos, dentro y fuera del Congreso de la Unión se impuso la decisión de paralizar los cambios: para los partidos políticos, cualquier cambio hacia una reforma electoral más racional era leído como un riesgo, como una posible afectación a sus intereses estratégicos en la búsqueda de los puestos de elección. El problema es que los partidos son los únicos que pueden cambiar las reglas del juego electoral, por eso las posibilidades de un acuerdo para modificar el modelo fue sólo una expectativa que terminó por evaporarse.

La sucesión presidencial de 2006 se jugó prácticamente con las mismas reglas que se crearon en 1996. No se calculó que las condiciones políticas de alta competencia, liderazgos personalizados y un esquema de campaña muy mediático generarían ríos de dinero público y privado para una campaña electoral larga, plagada de spots para hacer propaganda sucia. No se calculó que los árbitros de la contienda estaban afectados por su origen y que su desempeño, muchas veces omiso, dejaría una autoridad sin capacidad para someter a los poderes reales, los terce-

4 Desde finales de 2003 el grupo de consejeros que dejó el IFE hizo un planteamiento completo de las reformas necesarias. 
ros que intervinieron para desequilibrar la competencia. En fin, no se calculó que el país podía regresar a situaciones que sólo habían quedado temporalmente en el pasado, pero que cuando hubiera condiciones adecuadas volverían a surgir, como sucedió.

\section{¿CÓMO SE CONSTRUYÓ ESTA ELECCIÓN?}

El proceso de sucesión presidencial se inició de forma temprana, prácticamente al terminar la elección intermedia de 2003 se dio el banderazo de salida. Bajo el pretexto de que se trataba de procesos "normales" de la vida política, empezó una sorda batalla dentro y fuera de los partidos políticos. La construcción de este proceso electoral tiene dos grandes etapas: la parte previa que se integra con las precampañas y la selección de los candidatos a la presidencia de la República. Pero este proceso tiene varios antecedentes importantes que marcan la sucesión presidencial de 2006. Acontecimientos como la renovación de los consejeros del IFE a fines de octubre de 2003, los video-escándalos de 2004 y, sobre todo, el proceso de desafuero de Andrés Manuel López Obrador, jefe de Gobierno del Distrito Federal durante 2005, fueron las huellas que cargaron las elecciones presidenciales. Luego vino la parte de las campañas, la jornada electoral, la crisis poselectoral y la calificación. Cada una de estas piezas forma el rompecabezas de estos comicios.

A continuación analizaremos tres preguntas: ¿cómo se conformó la boleta electoral de 2006?, ¿cómo se construyó la guerra sucia? y ¿qué proporciones tiene la mancuerna entre dinero público y medios masivos?

\section{Las precampañas y la selección de candidatos}

Durante 2005, antes de iniciarse los procesos internos en los partidos para elegir a sus candidatos - fase de las precampañas que había llegado para quedarse-, había una evidencia crítica de que no existía ninguna regla para normar estos procesos 5 .

${ }^{5}$ El PAN y el PRD establecieron los montos autorizados para el gasto de
La lógica de las precampañas consiste en gastar en medios para lograr una mejor posición en las preferencias electorales. El panorama de las precampañas de la sucesión presidencial mostró los siguientes componentes: el PAN tuvo a cuatro aspirantes y, según una medición, las intenciones de voto entre los militantes eran: Santiago Creel con 48\%, Felipe Calderón con 29\%, Francisco Barrio con 15\% y Alberto Cárdenas con $8 \%$. En cambio, el Partido de la Revolución Democrática (PRD) sólo tenía a dos precandidatos, pero uno de ellos, Andrés Manuel López Obrador, contaba con una intención de voto entre los militantes cercana a 97\% (encuesta GEA-ISA, 18 de mayo de 2005). Dentro del PRI había dos frentes, el de Roberto Madrazo, líder del partido en esa época, con la intención más alta de voto entre las bases del tricolor, y el grupo "Unidad Democrática", conocido popularmente como el Tucom (Todos Unidos contra Madrazo), en el cual las dos posibilidades más visibles eran el senador Enrique Jackson y el gobernador del Estado de México, Arturo Montiel. Los otros integrantes de ese grupo eran Enrique Martínez (gobernador de Coahuila), Tomás Yarrington (ex gobernador de Tamaulipas) y Manuel Ángel Núñez (ex gobernador de Hidalgo).

Un año antes de la elección se manejaba en la opinión pública un conjunto de supuestos que, unos meses después, tuvieron modificaciones importantes. Como ejemplo se puede establecer que las percepciones a un año de la contienda eran:

a) Sobre el PRI había una imagen de caso resuelto, un partido con una maquinaria muy poderosa y enormes sumas de dinero, por lo que su regreso a Los Pinos podía ser como un día de campo. Además, se daba como un hecho que su candidato sería Roberto Madrazo.

\footnotetext{
las precampañas; en el PRI cada precandidato contrató su campaña en los medios con un gasto de millones de pesos que nadie fiscalizó. Los perredistas, que hacen elecciones abiertas, autorizaron sólo 7.5 millones de pesos ( 680 mil dólares); en cambio, los panistas se fueron a un presupuesto alto de 350 millones de pesos (31 millones de dólares). El PAN decidió hacer una elección interna sólo para sus militantes $\mathrm{y}$ adherentes (militantes en proceso de incorporación), que suman un poco más de un millón de votantes; en cambio, el PRD planeó su elección abierta, en la cual cualquier ciudadano podía participar, además de los militantes, los simpatizantes.
} 
b) Sobre el PRD, la visión era la de un partido con deficiencias importantes y estructura débil, pero el argumento era que su candidato "único", López Obrador, podría remontar la adversidad porque así lo mostraban los datos de las encuestas.

c) Del otro lado del tablero aparecía un PAN que navegaba sin tener el viento a su favor; ese partido tendría que pagar los costos de la administración del presidente Fox y las mediciones sobre intención del voto lo ubicaban en un tercer lugar. En ese escenario, Santiago Creel aparecía como el candidato más probable y predestinado a la derrota.

Estos tres supuestos tuvieron un reacomodo porque la mayor parte de las piezas que formaron la sucesión presidencial faltaba por resolverse.

El proceso para definir candidatos a la presidencia de la República dejó las primeras huellas de una batalla. El arreglo político en cada partido expresaba el nivel de institucionalización interna para resolver la selección. En el caso del PRI se impusieron las inercias del viejo autoritarismo; en el PAN sacaron a su candidato de un proceso de votación interna. En el PRD no hubo competencia, por lo que el conflicto se mantuvo dentro de un perfil bajo. La competencia interna mostró una ruta complicada para los partidos y los aspirantes.

Las reglas que definió el PRI no le sirvieron para evitar los rompimientos de la legalidad, los golpes bajos, la publicación de los trapos sucios y la generación de un clima tenso. En el PAN la legalidad se llevó a cabo, pero también hubo conflictos. Sin embargo, los márgenes de ventaja del ganador y el reconocimiento de la derrota de los perdedores le dieron al panismo una solución política que alejó cualquier amenaza de fractura. El costo de las precampañas dejó un saldo importante: los que más gastaron no fueron los ganadores - Arturo Montiel gastó más de 153 millones de pesos y Santiago Creel, 200 millones—6.

\footnotetext{
${ }^{6}$ El diario El Universal hizo una medición de los gastos de las precampañas; estos datos aparecieron el 24 de octubre de 2005. Las cifras sobre el costo de los tiempos deben tomarse con cierta precaución, y de hecho fue la crítica que se hizo a este monitoreo porque los costos reales no necesariamente corresponden con los tiempos y montos publi-
}

El optimismo inicial del PRI empezó a caer. Con la renuncia obligada de Montiel por la evidencia pública de corrupción durante su gestión, el Tucom, que se había mostrado públicamente como "un ejemplo" de modernización priísta, se quedó sin competidor. Una sombra de corrupción volvió a cubrir a ese partido porque Madrazo, el otro competidor, acumulaba una larga historia iniciada más de una década antes con el gasto de su campaña por la gubernatura de Tabasco, en la cual se contabilizaron más de 70 millones de dólares simplemente para una gubernatura. Sin que se supiera bien de dónde había venido el golpe contra Montiel, lo cierto fue que el impacto provocó una caída en las encuestas de opinión.

El barco tricolor, que parecía muy seguro para cruzar la campaña de 2006 y llegar a puerto en una ruta victoriosa, tenía descomposturas importantes. Al desplome de Montiel, que en esos momentos se volvió un paradigma para ejemplificar la corrupción pública priísta, se le sumó el enfrentamiento entre Elba Esther Gordillo y Madrazo y su extensión al sindicato de maestros. La nueva fractura al interior del PRI actualizó la salida hormiga en un mercado de alianzas muy activo. Era paradójico, pero el partido que durante los últimos años fuera el contrincante fuerte, ganador de gubernaturas y que salió mejor posicionado en 2003 , ahora se encontraba frente a un escenario muy diferente, con el viento en contra. Este caso ejemplifica las diferencias que existen entre la pista de las elecciones locales —en la cual la maquinaria tricolor ha tenido un desempeño muy eficiente a un costo económico muy alto, pero donde logró mantener y recuperar posiciones - y la pista de una elección nacional, en la cual se pone en juego otro tablero distinto.

En unas cuantas semanas el escenario modificó los supuestos, y de un PRI que iba en marcha triunfal hacia la presidencia se pasó a un partido con problemas y una intención del voto a la baja. El panismo, que presagiaba un rotundo fracaso, logró recomponerse y sacar un candidato competitivo, con lo cual detuvo su caída libre hacia la derrota y regresó con legitimidad a la competencia. En el PRD, con su candidato López Obrador, sin competen-

cados, ya que cada precandidato podía haber hecho un arreglo con las empresas televisoras y ese dato no era público. 
cia interna debido a que Cárdenas se retiró de la contienda, se consiguió evitar una ruptura visible y costosa, además de que su candidato logró permanecer como el puntero en las encuestas de opinión.

Para el tricolor, todo este proceso dejó altos contrastes, rompimientos, fracturas, heridos, mucho dinero y guerra sucia, es decir, hemos visto a este partido concentrado en su elemento, en sus inercias. El caso del PAN resultó diferente. Si se pudiera comparar el grado de enfrentamiento y conflicto, el panismo tuvo un proceso mucho menos estridente. Los panistas siguieron la bitácora que marcaron en sus reglas y llevaron adelante su proceso de tres rondas. El conflicto fue más acotado; se dio principalmente en torno a dos casos - Veracruz y Yucatán- y no pasó de la anulación de algunas casillas. A pesar del ruido que se hizo por estos casos, de forma comparativa el conflicto se mantuvo dentro de los cauces institucionales y, con el resultado de la tercera ronda, se terminó por completo. Los litigios del panismo tuvieron muy poco impacto externo.

Calderón ganó las tres elecciones (51.5\%) en un proceso en el que vino desde atrás y rebasó a Santiago Creel $(31.9 \%)$, que punteaba en las encuestas previas; Alberto Cárdenas no salió de un lejano tercer lugar (16.5\%). Hubo competencia, debate y elecciones. Además, los perdedores cerraron filas con el ganador. El panista resultó una opción atractiva para dos tipos de grupos: los que no veían en Creel a un candidato competitivo y que pensaban irse con cierta resignación con Madrazo; y para otros sectores que no querían el regreso del PRI y con mucha resistencia pensaban en la opción de López Obrador.

Los dos nuevos partidos tuvieron un estreno problemático. El caso de Alternativa (Partido Alternativa Socialdemócrata y Campesina, PASC) tuvo un tropiezo por el conflicto interno que generó la candidatura. La parte que representaba el ala campesina del partido quiso madrugar la candidatura de Patricia Mercado y sustituirla por la de Víctor González Torres, alias el Dr. Simi. Este personaje - presente durante todo el proceso- es el clásico subproducto de un sistema de reglas en en el cual el dinero y la capacidad de tener presencia mediática son casi suficientes para tener una candidatura. Sin embargo, el IFE impidió la usurpación de la candidatura que quiso hacer el sector campesino del partido. La ruptura también provocó que la candidatura de Mercado no contara con recursos durante la mayor parte de la campaña, porque el encargado de las finanzas del partido era del grupo que apoyaba al Dr. Simi. De aquí surgió la primera división que terminó en una ruptura entre grupos que sólo se juntaron para obtener el registro, pero que no compartían ni el proyecto ni la estrategia.

El caso de Nueva Alianza (Panal) tuvo la sombra y manufactura de la lideresa del magisterio, Elba Esther Gordillo. Una vez que rompió con Madrazo y que le impidieron ser la presidenta del PRI, reconoció el apoyo que había dado al nuevo partido. Cuando la elección ya había sido calificada, salió a la luz pública una versión de cómo se había hecho ese partido. Un ex dirigente de la Asociación Ciudadana del Magisterio — antecedente del Panal rompió con la lideresa del magisterio y divulgó que, para hacer el partido, se usaron 450 millones de pesos que eran recursos de tres fideicomisos de vivienda manejados por el Sindicato Nacional de Trabajadores de la Educación (SNTE). El ex dirigente habla de una estructura de 152 mil cuadros expertos en ingeniería electoral, que es la base desde la que se hizo ganar a la pareja Gordillo-Madrazo la dirección del PRI y desde la que se operaron varios comicios locales y, por supuesto, las elecciones de $2006^{8}$.

La boleta electoral de 2006 quedó conformada por Felipe Calderón, Madrazo y López Obrador. El PAN no hizo alianzas; en cambio, el PRD se alió con el Partido del Trabajo (PT) y Convergencia, para formar la Coalición por el Bien de Todos (CPBT). El PRI hizo alianza con el Partido Verde Ecologista de México (PVEM) y formó la Alianza por México (APM). Para tener el cuadro completo de candidatos a la presidencia, hubo también otros dos candidatos de los nuevos partidos: Patricia Mercado por el Partido Alternativa Socialdemócrata y Campesina, y Roberto Campa por el Partido Nueva Alianza ${ }^{9}$.

\footnotetext{
${ }^{7}$ Una extraña reforma electoral que se hizo para establecer el mecanismo de creación y solicitud de registro para nuevos partidos fijó que sólo se podía hacer a través de las Agrupaciones Políticas Nacionales (APN); fue como un prerrequisito para formar nuevos partidos.

${ }^{8}$ Entrevista al ex dirigente Noé Rivera, El Universal, 21 de septiembre de 2006.

${ }^{9}$ Los nuevos partidos están impedidos de ir en alianza en su primera
} 


\section{Una campaña sucia: muchos spots y poco debate}

En cualquier hipótesis, 160 días son muchos para una campaña por la presidencia. Después de una inédita pausa decretada por el IFE — la tregua navideña—, se inició formalmente la campaña electoral. Con amplios y fatigosos antecedentes, el inicio de este proceso fue un movimiento lento porque la tregua vacacional sí logró enfriar los ánimos que dejaron las precampañas.

Con los largos antecedentes se notaba cierto cansancio. Los escándalos y las rupturas habían caracterizado la fase previa a la campaña. Además, a diferencia de otras campañas, en esta ocasión no había novedades importantes. Se jugaba con las mismas reglas del juego; los candidatos eran muy conocidos, sobre todo Madrazo y López Obrador; Calderón había tenido menos exposición mediática y, además, llegó con una desventaja inicial, un poco de improvisto.

A lo largo de esos meses hubo una intensa campaña mediática de spots en televisión y radio. Pero no todo fue igual, hubo momentos que marcaron etapas en ese largo trayecto. El inicio formal tuvo una primera fase que duró dos meses, lo que se puede considerar como el arranque de las candidaturas. Sin acontecimientos que llamaran particularmente la atención, el cuadro inicial marcaba una intención de votos de 38.7\% para López Obrador, que confirmaba su posición de puntero; luego estaban muy cercanos Calderón, con 31\%, y Madrazo, con 29.2\% (encuesta Mitofsky, enero de 2006).

Esa distribución de las intenciones del voto se mantuvo durante los dos primeros meses. Esta fase llega hasta mediados de marzo, momento en que las elecciones locales del Estado de México establecen que los primeros movimientos no lograron alterar las posiciones y que el puntero consolidaba su cómoda ventaja. Parecía que López Obrador se había instalado en una inercia ganadora.

Entre el Estado de México y la elección federal había demasiadas diferencias, pero existía espacio para que se

contienda y para mantener el registro necesitan obtener $2 \%$ de los votos. Hubo otro caso de alguien que no logró una candidatura, Jorge Castañeda, quien hizo un intento para obtener un registro como candidato independiente. El expediente llegó hasta la Suprema Corte de Justicia de la Nación, organismo que dictaminó de forma negativa. expresara un cierto clima político. En ese proceso local la abstención fue alta (40\%) y pudo deberse a varios factores, como el efecto Montiel que, al parecer, no derrumbó el voto del PRI, pero sí le ocasionó daños importantes ya que le bajó el voto respecto a las elecciones de 2003 y 2005. Otro factor fue la saturación, ya que en menos de un año los ciudadanos de ese estado estuvieron sometidos a dos procesos locales. La abstención también pudo ser resultado de una campaña presidencial que, después de casi dos meses, no terminaba de despegar y no entusiasmaba, a pesar del alto costo y la enorme cobertura diaria de los candidatos en los medios masivos.

En ese contexto algo se conectó entre el repunte local del PRD y la opinión de $42 \%$ de la población, que consideraba que López Obrador ganaría la presidencia el 2 de julio ${ }^{10}$. La campaña de López Obrador en el Estado de México no era un evento nuevo. El año anterior, durante la elección para gobernador, tuvo una presencia quizá no tan pronunciada como la de 2006, pero que fue una apuesta por el contagio y la vecindad con el bastión que representaba la fuerza del PRD en el Distrito Federal. En 2005 sólo se logró que el PRD mantuviera sus votos, en cambio, en 2006 el incremento fue importante, sobre todo en un contexto de fuerte abstencionismo. El PRD pasó del tercero al segundo lugar, subió de 10 a 17 distritos de mayoría, rozando los talones al PRI, y sería el partido que gobernaría más población. Las dos encuestas citadas le daban a López Obrador una ventaja de diez o más puntos respecto a Calderón, y de 16 a 18 puntos respecto a Madrazo, que se hundía en un tercer lugar lejano, según el criterio de votantes probables ${ }^{11}$.

\footnotetext{
${ }^{10}$ Dos encuestas coincidían en esa percepción: El Universal (13 de marzo de 2006) y Reforma (16 de marzo de 2006).

${ }^{11}$ El 12 de marzo de 2006 el PRI no ganó casi ninguno de los municipios más poblados, los cuales quedaron en manos del PAN y del PRD, pero conservó su voto rural y, también, se ubicó como el segundo en la competencia (con excepción de Tlalnepantla), ya sea con el PAN en el corredor azul (Naucalpan, Atizapan, Cuatitlán Izcalli, Tlalnepantla y Toluca) o con el PRD en el oriente del estado (Neza, Chalco, Valle de Chalco Solidaridad, Texcoco). El PRD ganó uno de los municipios más poblados del país, Ecatepec, que tiene un listado nominal de $932 \mathrm{mil}$ votantes. De nueva cuenta, el Estado de México tuvo un perfil tripartito, en el cual la diferencia entre el primer y tercer lugar - PRI y PAN - fue de siete puntos porcentuales (267 mil votos); la diferencia entre el primer y segundo lugar - PRI y PRD - fue de tres puntos porcentuales (unos 130 mil votos).
} 


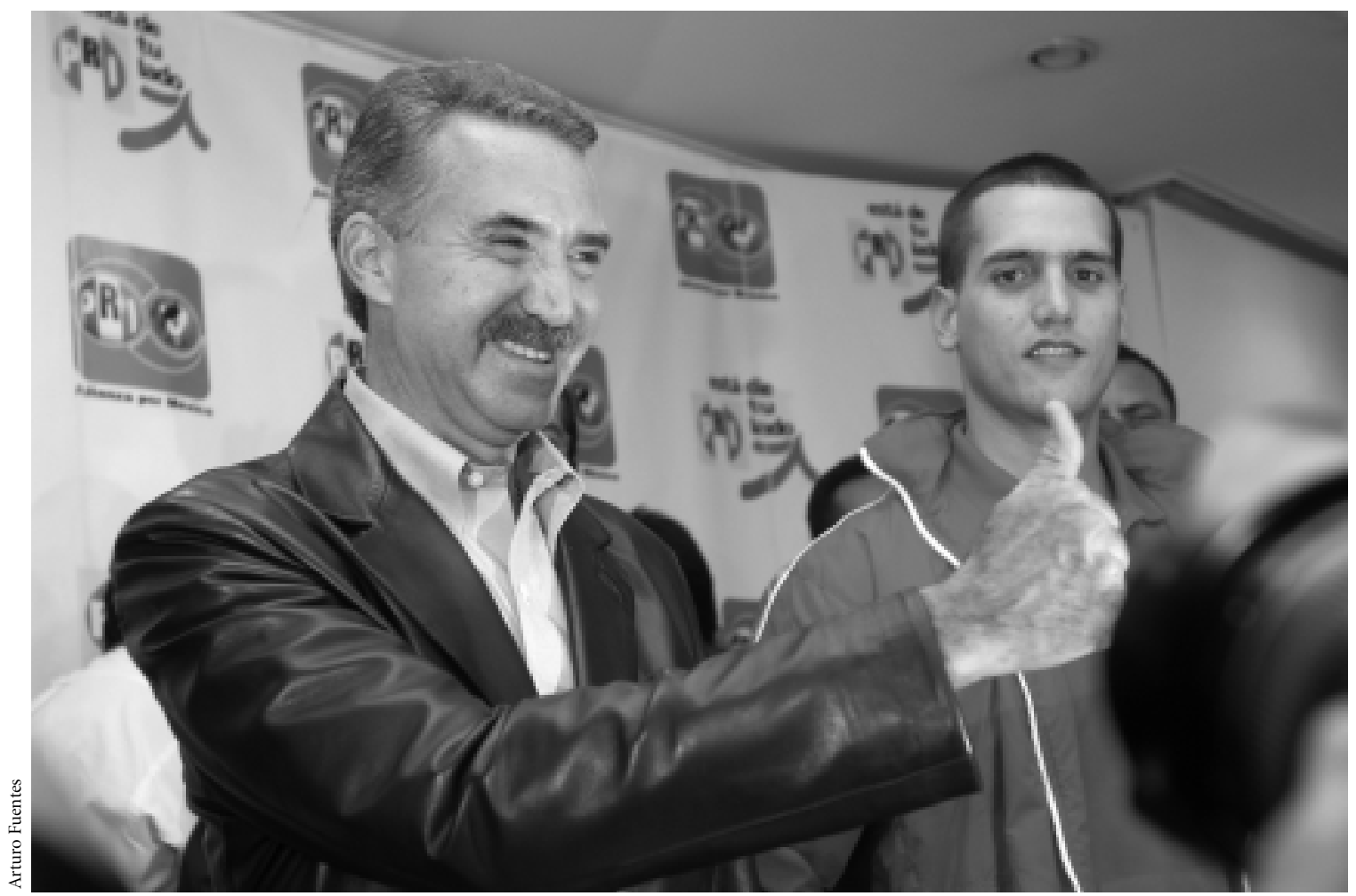

Roberto Madrazo (PRI) y Jorge Emilio González (PVEM).

El PAN no logró la famosa "revancha" que anunció Calderón y una vez más quedó enmarcado en sus zonas de voto duro, su corredor azul. El hecho de pasar al tercer sitio fue un factor negativo, que sumado al momento de la campaña presidencial, con un candidato estancado, dieron como resultado que la ecuación panista siguiera sin encontrar la manera de crecer. Mientras que el candidato del PRD logró mover a su partido al alza, los otros dos no lo consiguieron y se quedaron prácticamente en sus números, con algunas bajas. Según la encuesta de $E l$ Universal, López Obrador subió de 40\% a 42\% entre enero y los primeros días de marzo; Calderón bajó de 33\% a 32\%, y Madrazo de $26 \%$ a 24\%, como el balance de la primera fase de la campaña ${ }^{12}$.

Otro dato importante de la inercia ganadora de Ló-

${ }^{12}$ El Universal, 13 de marzo de 2006. pez Obrador hasta ese momento era la percepción de que se trataba del candidato que menos había gastado en la campaña. Parecía que algo se había fracturado entre dinero y mercadotecnia, por un lado y, por el otro, popularidad y confianza. Esta tendencia tendría que pasar todavía varias pruebas: la primera era el tiempo que faltaba —más de 100 días para la elección—, y muchas batallas quedaban pendientes. ¿Qué tendría que pasar para que las cosas cambiaran?

Después de un reconocimiento público de que la campaña de Calderón no daba resultados, se inició un cambio drástico en la estrategia, un nuevo tono caracterizaría el mensaje del PAN. En el PRI se hizo el mismo cálculo: había que pegarle con todo al puntero, particularmente ante al primer debate entre los candidatos. Así se inició la segunda fase de la campaña electoral de 2006.

En un ensayo sobre Felipe Calderón, Sabina Berman desliza lo que pudo haber sido la chispa para hacer de la 
campaña una guerra sucia. La escritora lo llama el "estilo cómico de contender" y dice:

Para febrero de 2006, según las encuestas del voto, Calderón se encontraba estancado diez puntos por debajo del puntero, AMLO [López Obrador]. Su suerte de benjamín parece no encender. Hasta que enciende. En un mitin, un perredista desde el público lo insulta. Micrófono en mano, Calderón camina hacia el borde del templete donde lo encara y le responde duro. Cito de la incierta memoria: "Bejarano, ése es del Peje. Ponce, el de Las Vegas, ése es del Peje, no de mi gente. La Padierna, ésa es del Peje”. Es decir, la corrupción campea en la gente del Peje, no en la suya. El pleito aviva a la multitud, que aplaude y se ríe. Eso es lo que los noticieros nacionales nocturnos rescatan del día de Calderón para difundir.

En los días siguientes vuelve a repetirse el fenómeno. Calderón ataca a AMLO: a su promesa de hacer un tren bala que cruce desde la capital del país a Tijuana la llama "mariguanada". La gente se ríe y los noticieros difunden el momento cómico [...].

Resulta que del otro lado del país, en la campaña del PRD, el candidato también descubre sus dotes cómicas. AMLO llama al presidente panista a no intervenir en la campaña. Micrófono en mano y guirnaldas de flores al pecho lo dice así: "Con todo respeto presidente: cállate, chachalaca" (Berman, 2006).

Mientras los partidos y sus candidatos acordaban cuántos debates sostener y con qué reglas, se inició el cambio mediático en las estrategias del PRI y del PAN contra López Obrador. Mientras el candidato de la Coalición por el Bien de Todos recibió el golpe, no quiso ver las consecuencias y decidió que, como puntero, no asistiría al primer debate. Después de varias reuniones, los partidos acordaron celebrar dos debates, uno el 25 de abril y otro el 6 de junio. De finales de marzo al primer debate se conforma una etapa caracterizada por una intensa guerra sucia que cambia el tono de la campaña y centra la disputa electoral en las reglas del juego y en el arbitraje de las autoridades.

Los panistas lanzan su lema de "López Obrador es un peligro para México", lo exhiben como un personaje parecido al presidente Hugo Chávez, de Venezuela, y en una actitud contra el presidente Fox; retoman de un mitin la frase que le dedica el candidato perredista de "cállate, chachalaca”. El spot llama la atención sobre el problema de la intolerancia y forma el inicio de un conjunto de misiles mediáticos que no se detendrá sino hasta el final de la campaña. De igual forma, el PRI lo exhibe como un político que no cumple su palabra y que miente con una gran habilidad.

En unos días, este proceso de campaña le pega a la intención del voto de López Obrador y, por primera vez en muchos meses, empieza a bajar en las encuestas. Para mediados del mes de abril, López Obrador había bajado cuatro puntos y se ubicaba en 38\%; a su vez, Calderón subía dos puntos para obtener $34 \%$ y acortar la distancia a sólo cuatro puntos porcentuales, en tanto que Madrazo permaneció casi igual, en 25\%. Esta medición se levantó entre el 5 y el 8 de abril ${ }^{13}$. Dentro de la volatilidad que mostraba el momento político se registró un cambio importante; según algunas mediciones que se hicieron dos semanas después, justo antes del debate, llegaron a mostrar, con todo y los márgenes de error de las encuestas (que no son ejercicios de precisión), que algo había cambiado, que la inercia ganadora de López Obrador se había roto y que la competencia mostraba uno de los rasgos que sería perdurable hasta el mismo día de las elecciones: la figura de una elección completamente cerrada entre López Obrador y Calderón, con Madrazo en un distante tercer lugar.

Cuando López Obrador decidió no ir al primer debate tenía una clara ventaja y una inercia ganadora. Al llegar la fecha de este encuentro, el candidato perredista se mantuvo en su palabra, pero el contexto registraba un cambio muy importante. Algunas encuestas empezaron a indicar un empate, e incluso algunas le daban una pequeña ventaja a Calderón. El día del debate un diario sacó la siguiente medición: López Obrador bajaba de 41\% a 35\% y Calderón subía de 31\% a 38\%; Madrazo bajaba dos puntos para ubicarse en $23 \%$, y se hacía una medición de los otros dos candidatos: Patricia Mercado, 2.6\%, y Campa, $0.6 \%$. Hubo malestar e incluso incredulidad; el propio candidato perredista desacreditó esas mediciones y habló de encuestas que nadie conocía, en las cuales seguía diez puntos arriba, pero en el clima de polariza-

\footnotetext{
${ }^{13}$ El Universal, 17 de abril de 2006.
} 
ción, que se agudizó en ese momento, la campaña tomó un perfil de confrontación que permanecería hasta el final ${ }^{14}$. Otras encuestas — GEA-ISA y Milenio — también registraron el cambio en las intenciones del voto.

Además de los spots había acontecimientos políticos que incidían; por ejemplo, la conformación de las listas para diputados y senadores que había generado problemas diferentes en cada uno de los tres grandes partidos: en el PRI hubo una deserción documentada, porque en la lógica de un improbable triunfo de Madrazo, para los priístas era necesario asegurar un lugar en el Congreso. En el PRD se observó, con mayor contundencia que nunca, el operativo para reciclar al PRI desertor del madracismo, que simplemente no alcanzó lugar en el tricolor. Lo que siempre ha hecho el PRD — reciclar priístas - fue, en esta ocasión, escandaloso, al grado de que se habló de la hipótesis de que López Obrador y el PRD serían otra versión del PRI. En el panismo hubo menos intercambios, pero no por impedimentos morales o políticos, sino simplemente porque el manejo del partido los limitón ${ }^{15}$.

A todo lo anterior hay que sumar la presencia permanente del presidente Fox hablando en contra de López Obrador, pero no directamente, no por su nombre, sino a partir de una construcción ideológica negativa que se ha hecho de López Obrador y que tiene como adjetivo central ser un "populista". En esa guerra de adjetivos, la respuesta de López Obrador se enganchó y cometió dos errores que le costaron la baja en las intenciones del voto: un discurso de intolerancia - "cállate, chachalaca"- y un tono duro de intransigencia. Cuando un candidato va ganando en la carrera presidencial, como era la situación de López Obrador, una actitud prudente hubiera sido ubicarse por encima o al margen, abrir espacios incluyentes hacia sectores que tenían dudas en apoyarlo, como el caso de los empresarios, y no entrar a la guerra sucia.

En ese momento de la campaña se pudo observar que el espacio electoral no estaba funcionando para conducir,

\footnotetext{
${ }^{14}$ Reforma, 25 de abril de 2006

${ }^{15}$ De cualquier forma, no faltaron casos, como fue el del diputado poblano del PRI, Moreno Valle; el ex gobernador de Oaxaca, Diódoro Carrasco, y el mismo senador Demetrio Sodi, quien fue el candidato panista a jefe de gobierno del Distrito Federal.
}

debatir y negociar. La política —si es que a esos hechos se les podía denominar así- estaba al servicio de una confrontación que cada día polarizaba más a la sociedad. Los candidatos estaban inmersos en el frenesí de los auditorios y las masas; la lógica del mitin se había apropiado del discurso de campaña. La lógica de la arenga era lo que predominaba, todo lo contrario a un debate democrático. Se mostraba lo peor de cada candidato y, al final de cuentas, paradójicamente, esa estrategia sí movía las intenciones del voto. Así pasó esta fase entre el primer y segundo debate.

Después del efecto que tuvo la ausencia de López Obrador en el primer debate, el lugar de los punteros tuvo un reacomodo y se estableció un porcentaje de votos a favor de Calderón, con 39\%, y López Obrador, con 35\%. Así transcurrió prácticamente el mes de mayo ${ }^{16}$. Durante los primeros días de junio se empató literalmente la competencia y los dos candidatos punteros llegaron al segundo debate con una intención de votos de 36\%; Calderón bajó tres puntos y López Obrador subió un punto; Madrazo estaba con $24 \%$, Mercado con $4 \%$ y Campa con cero $^{17}$.

Con el segundo debate se inició la fase final de las campañas; los dos punteros llegaron prácticamente empatados y sucedió lo que era previsible: se prolongó la polarización entre Calderón y López Obrador. Era muy difícil romper el empate, se necesitaba que alguno de ellos resbalara e hiciera un ridículo notorio, pero con un formato de debate tan protector, esa posibilidad estaba descartada. La medición posterior al debate volvió a expresar un leve movimiento en las intenciones del voto con ventaja para Calderón, que subió un punto para llegar a 37\%; López Obrador bajó dos, para quedar con 34\%. Cabe aclarar que la diferencia entre ambos era menor al margen de error de la encuesta que manejó $\pm 3.4 \%$. Madrazo bajó a 22\% y Mercado subió a 6\%, junto con Campa, que llegó a $1 \% 18$.

Sin embargo, el posdebate, que es muchas veces el momento decisivo que define ganadores y perdedores, ge-

\footnotetext{
${ }^{16}$ Dos encuestas mostraron ese resultado: El Universal (15 de mayo de 2006) y Reforma (24 de mayo de 2006).

${ }^{17}$ El Universal, 6 de junio de 2006.

${ }^{18}$ El Universal, 12 de junio de 2006.
} 


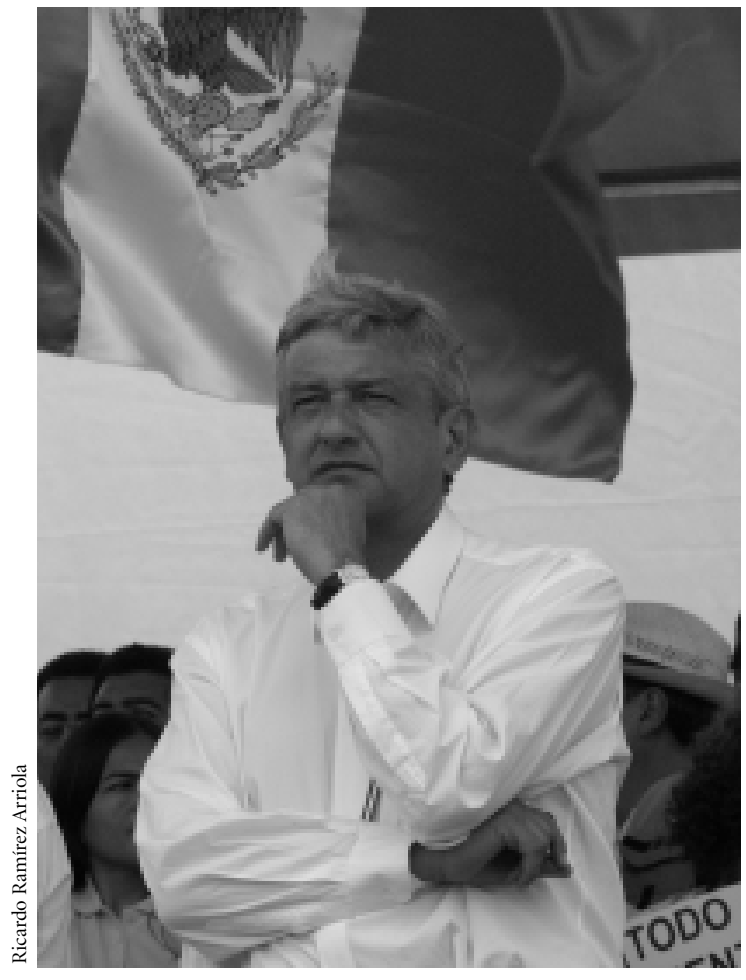

Andrés Manuel López Obrador, segunda asamblea popular, Zócalo de la ciudad de México, 15 de julio de 2006.

neró un nuevo pleito por el expediente de un cuñado de Calderón, que se conoció como el caso "Hildebrando". La maquinaria de la propaganda sucia se tragó el debate y uno de los pocos momentos en los que se pudo ver la confrontación de propuestas quedó en el olvido porque el posdebate se centró en el caso del cuñado de Calderón. La estrategia política del PRD fue una respuesta puntual en la cual se construyó una imagen de deshonestidad de Calderón, cuyo lema de campaña era "las manos limpias”. Se le involucró en el caso del Fobaproa y se hizo una campaña mediática para devolver los golpes de la guerra sucia que el panismo sembró contra López Obrador.

Aquí se aplica la sentencia de que el que pega al último, pega más duro. Sin embargo, con lo cerrado de las preferencias era difícil calcular si estos golpes moverían de nuevo las intenciones del voto. A pesar de que el recurso del escándalo había sido usado hasta el cansancio, todavía parecía tener impacto social.
Uno de los pocos méritos del debate es que dejó establecida la clave de la elección de 2006: una disputa entre dos proyectos de país, que pueden caracterizarse desde diferentes ejes discursivos: izquierda versus derecha, eficiencia versus distribución, pasado versus futuro, privilegios versus derechos, liberalismo versus nacionalismo, etc. La polarización en la que se encontraba el país no era explicable sólo por las estrategias de guerra sucia, sino que tenía vinculaciones más profundas. Como pocas veces ha sucedido en México, una decisión electoral parecía ser importante para los próximos años.

Tanto el empate como la polarización eran dos problemas complicados y difíciles de resolver. Cuando se planteaban los mínimos que necesitaba México para los próximos años — por ejemplo, estabilidad y mejor distribución del ingreso- - parecía que ninguno de los punteros podía ofrecer las dos partes, ya que los acentos de cada uno de los candidatos sólo tocaban una parte de esa pareja. Cuando se pensaba en la urgente necesidad de tener un país con menor desigualdad y, al mismo tiempo, una mejor construcción institucional, sucedía lo mismo: ninguno garantizaba ambos requerimientos. Así en cada uno de los grandes problemas nacionales. De un lado se observaba a un candidato que se presentaba como de izquierda, pero con una operación al viejo estilo prísta que no garantiza una modernidad política. Del otro lado estaba un candidato con un estilo gerencial que confundía conceptos tan importantes como gobierno de coalición y gobierno de unidad nacional, dos cosas completamente diferentes.

Algo similar sucedía con la seguridad: Calderón mostraba una faceta con aire autoritario y repetía el discurso de respeto a la ley y al estado de derecho, junto con la frase de "mano firme". Para López Obrador, la seguridad se resolvía con el combate a la pobreza, más negociación y más intervención del ejército. En ambos casos quedaba la certeza de que no se entendía la dimensión de un problema complejo.

En suma, nos preguntamos: ¿se trataba de dos proyectos de país o simplemente de dos estilos, dos acentos, con una jerarquía de políticas públicas distinta? Lo cierto era que el país estaba ante dos incertidumbres: la que representaba López Obrador con signos de restauración, o la 
de Calderón, que con su excesivo conservadurismo podría agravar el clima social mediante una política de mano dura, como una salida fácil para un país agraviado por una gran desigualdad social. En el fondo, lo que la polarización expresaba era que ninguno de los dos punteros le garantizaba a la otra parte una inclusión satisfactoria.

Doce días antes de la elección se registró un empate entre los dos punteros. La fase final de la campaña era como una noche incierta; no se sabía quién ganaría el 2 de julio y esa incertidumbre abrió un momento en el que los actores políticos intentaron dar su golpe final, sin importar los efectos negativos sobre un clima ya tenso y polarizado. Al final de la campaña los partidos enloquecen y firman pactos en los cuales declaran que sí van a respetar las reglas y los resultados, cuando se supone que esa es una obligación y no una concesión. Mientras, la guerra de los expedientes sucios seguía su desarrollo a toda velocidad, los golpes bajos se intensificaban y la reproducción frenética de spots parecía no tener fin.

Además de la incertidumbre, había cierta frustración porque después de un gasto de casi cinco mil millones de pesos, una larga campaña sumada a una etapa de varios años de luchas y cálculos, en los cuales la clase política había mantenido en suspenso pactos y acuerdos necesarios para el país, resultaba que a unos cuantos días del final no había nada seguro para nadie.

Unas encuestas daban la ventaja a López Obrador y otras a Calderón. De la misma forma, unos encuestadores indicaban que la final sería entre tres candidatos —en ese resultado incluían al priísta- y, para otros, la final era sólo entre los dos punteros. Hubo varias novedades en este proceso, con la aclaración de que casi todos los ingredientes ya se habían visto, quizá sin el nivel de profundidad que hubo en 2006. Por ejemplo, la incertidumbre no se había experimentado de esta manera, en un empate abierto; lo mismo sucedía con la polarización entre proyectos, una tensión que había trasminado los ánimos y logrado dividir a la sociedad. No era difícil prever que, después del 2 de julio, el conflicto sería un ingrediente de la fase poselectoral. Otra novedad fue la oscilación en las preferencias, medida puntualmente por las encuestas, como consecuencia de un uso estratégico de la televisión, escenario que ya habíamos visto en el año 2000, pero no con la contundencia de este proceso. Si las campañas ya se habían convertido en mediáticas, la de 2006 tuvo como centro dominante ser una campaña de medios.

Además de lo mediático, otra de las claves del 2 de julio estaría en las estrategias de movilización, en la capacidad de los partidos para poner en operación a sus estructuras territoriales y llevar a la gente a votar. Esa era la apuesta final que haría el PRI, aunque había muchas dudas de que este recurso les alcanzara para darle la vuelta a un marcador que los había mantenido en el tercer lugar de forma permanente. Lo mismo le pasaba al PRD: sus redes y estructuras territoriales eran una apuesta; sin embargo, la división política del país, los territorios y bastiones de los partidos marcaban enormes áreas donde la debilidad estructural del Sol Azteca le complicaba el panorama. Por el lado del panismo sucedía algo parecido, pero inversamente proporcional al perredismo: las zonas del centro y sur del país eran, salvo algunos manchones urbanos, territorios blanquiazules débiles. Por eso, ambos punteros dependían de las franjas de prí́stas que entraran al carril del voto útil ante la anunciada derrota de Madrazo y del voto independiente. Migrar el voto por la presidencia hacia cualquiera de los punteros para ejercer su segunda opción de voto y conservar el voto por sus candidatos al Congreso era una posibilidad. Esta eventualidad tampoco resolvía el empate, porque mantenía casi por partes iguales las preferencias príistas por una segunda opción.

Días antes de los comicios había una preocupación evidente por el resultado de la jornada del 2 de julio; sin embargo, una vez pasada la elección lo más complicado sería la etapa siguiente en la que ninguno de los actores quiso definir una estrategia poselectoral. Cerca de las elecciones se podían plantear algunos escenarios:

a) Diversas voces señalaban que una de las claves más importantes, quizá la definitiva para transitar el 2 de julio de la incertidumbre a la certidumbre, sería un resultado abierto que rompiera el empate entre los dos punteros. Esa sería la manera de alejar un conflicto $y$, sobre todo, de un largo litigio jurisdiccional.

b) En el caso contrario, de mantenerse un empate, representaba un problema. Reconocer la derrota era la vía 
para pasar a otra etapa en condiciones de gobernabilidad democrática; sin embargo, con la polarización había dudas sobre un manejo institucional.

c) No reconocer la derrota conducía a otros escenarios y posibilidades, como lo que había sucedido en procesos anteriores al de México, sobre todo en Estados Unidos, Costa Rica y en Italia, incluso en Alemania, en los cuales los empates generaron litigios que mantuvieron el resultado en el aire durante varias semanas ${ }^{19}$. En el caso mexicano el escenario conflictivo planteaba que la elección se impugnaría ante el TEPJF, con lo cual la solución final se sabría dos meses después del 2 de julio.

d) Otro escenario era el de la sorpresa, como sucedió en 1994 con Nicaragua, en donde las encuestas marcaban una tendencia y la elección generó un resultado no previsto. El espacio de las sorpresas podía tener diversas salidas, como un triunfo muy poco probable del PRI, o un triunfo amplio de alguno de los dos punteros, PAN o PRD.

Los 160 días de campaña llegaron al final. Había en el ambiente de esos días expectativas ambivalentes; por una parte, el hartazgo de tantos meses de spots de radio y televisión, en los cuales predominó un mensaje de propaganda sucia; por la otra, el fin de un proceso electoral rodeado de incertidumbre sobre quién ganaría.

Los procesos sociales no tienen pausas y en este caso era palpable que México tenía por lo menos tres años de un pleito que parecía no terminar. Por eso el país llegó exhausto a las elecciones del 2 de julio. Cuando se contabilizan los antecedentes destaca una prolongada confron-

\footnotetext{
${ }^{19} \mathrm{El} 7$ de noviembre del año 2000 hubo en Estados Unidos un proceso que duró 35 días para conocer la decisión final y al ganador, entre Bush y Gore, que sólo tuvieron una diferencia de $0.51 \%$; la decisión final estuvo a cargo de la Suprema Corte. El 18 de septiembre de 2005, en Alemania se dilató el proceso 22 días para conocer al ganador de la elección entre Merkel y Schroeder, conflicto que se solucionó con la formación de un gobierno de coalición. El 5 de febrero de 2006, en Costa Rica, la diferencia entre Arias y Solís fue de 1.12\% y el Tribunal Supremo de Elecciones realizó un recuento manual de votos. Por último, el 9 de abril de 2006, la diferencia entre Prodi y Berlusconi fue de $0.1 \%$ y la Corte Suprema de Casación hizo un recuento de votos; el conflicto duró nueve días. Datos de Enfoque, núm. 644, suplemento de Reforma, 23 de julio de 2006
}

tación: 2004 fue el año de los video-escándalos; 2005, el año del desafuero, y 2006, el de la polarización electoral. El enfrentamiento era inevitable, pero la forma que tomó surgía, en buena parte, de las reglas del juego de las campañas: del modelo de financiamiento público de los partidos y del esquema de acceso a los medios masivos.

Los meses de campaña fueron como colocar a cinco niños beligerantes en una pequeña casa de cartón, dándole a cada uno una caja de cerillos. Era prácticamente un hecho que en algún momento alguien empezaría a prender fuego.

La campaña de 2006 era como un regreso a 1994, al voto del miedo, a los candidatos y proyectos que se presentan como la polarización entre la izquierda y la derecha, entre cambio y continuidad, entre "un peligro para México" o la derecha corrupta que quiere mantener los privilegios de las élites. La intolerancia del spot inundó el clima político y la campaña se convirtió en un televisor asfixiante. Durante las etapas del proceso cambiaron varias veces las preferencias electorales como una respuesta directa a las estrategias de guerra sucia: primero, López Obrador dominó la ventaja (enero-marzo); luego, Calderón subió y se colocó en primer lugar (abril-mayo); más adelante se empataron las preferencias (primeros días de junio) y, en la parte final, había un escenario cerrado: de trece encuestas, ocho le daban una ventaja a López Obrador, con un porcentaje que iba desde 32\% hasta 36\% (Parametría, GCE, Indermerc, Milenio, Universidad de Guadalajara, Mitofsky, Reforma, El Universal); y cuatro le daban ventaja a Calderón, con números que iban de $34 \%$ a $39 \%$ (Arcop, Zogby, Alducin y GEAISA). Una encuesta señalaba el empate en $34 \%$ (BGC). En lo que sí coincidían las trece encuestas era en el tercer lugar para Madrazo.

En el año 2000, a unos días de la elección, la mayoría de las encuestas indicaban que Labastida estaba arriba y sólo unas cuantas señalaban que Fox tenía ventaja. Con base en esa experiencia, algunas opiniones señalaban que tal vez el 2 de julio el escenario podría ratificar la ventaja de López Obrador y ganar la elección con una diferencia clara, como sucedió seis años antes. Sin embargo, también podía suceder lo contrario, por medio de dos mecanismos: uno sería porque el grupo de indecisos $-12 \%$ 
según Reforma - se inclinara por Calderón, un voto más de corte conservador; y el otro, por un cambio en las preferencias sobre la segunda opción de voto de los priístas que, de acuerdo con El Universal, era de $29 \%$ por Calderón y de sólo 16\% por López Obrador. Al final, todos los números indicaban un resultado incierto.

En el tramo final de la campaña se perdió la prudencia, se agudizó la confrontación y se lastimaron más las reglas del juego. Hubo una cantidad de spots que aturdieron al auditorio. Los organismos empresariales, bajo las siglas del Consejo Coordinador Empresarial, le entraron de lleno al negocio de los spots, con un discurso similar al panista ${ }^{20}$; la Iglesia católica también presionó y se ubicó políticamente en el escenario electoral. El frustrado candidato Víctor González Torres no dejó de hacer propaganda en los medios masivos. Varias centrales sindicales también hicieron pública su preferencia de voto a favor de la Coalición por el Bien de Todos. Y la joya de la corona fue el presidente Fox, que estuvo en campaña todos los días, como una suerte de vocero de Calderón.

Después de los millones de pesos gastados por los candidatos en spots mediáticos, el escenario expresaba un alto grado de insatisfacción. Las dos principales opciones no habían logrado despejar las dudas. Las opiniones ciudadanas de un voto por "el menos malo" eran nutridas; ni Calderón ni López Obrador garantizaban la construcción de la siguiente fase de la democracia mexicana, la consolidación y el cambio de las reglas. López Obrador no se distinguió como jefe de gobierno del Distrito Federal por ser un gobernante preocupado por la transparencia y la democracia. Calderón y los panistas tampoco acumulaban para ese momento buenas credenciales democráticas después de lo que habían hecho con el IFE, la ley de radio y televisión y la jugarreta del desafuero ${ }^{21}$.

\footnotetext{
${ }^{20}$ Las acciones del IFE en esta materia quedaron muy cortas; se limitaron a enviar cartas en las cuales se exhortaba a los actores a suspender esas campañas de medios, pero no se llevaron a cabo acciones importantes para generar un entorno de equidad y respeto a la legalidad. Con una confrontación tan fuerte, era difícil que simples exhortos hubieran sido el mecanismo para detener la avalancha. Si el propio IFE se había mostrado omiso frente a la "guerra sucia" de los partidos, no era esperable una actitud firme ante los terceros que intervinieron de forma facciosa, sobre todo en la fase final de la campaña.

${ }^{21} \mathrm{La}$ reforma a la ley de radio y televisión y las telecomunicaciones que
}

\section{El financiamiento público y el gasto en medios}

El cemento que une las piezas de esta campaña es el financiamiento público y el esquema de acceso a los medios de comunicación masivos. Las otras piezas del modelo fueron el perfil de las campañas sucias y, sobre todo, la incapacidad del IFE para moderar y detener la "guerra sucia” y la intervención facciosa de otros actores. Todos estos ingredientes formaron el rompecabezas de 2006.

Desde antes de que se iniciara formalmente el proceso electoral, el IFE hizo sus previsiones presupuestales y estableció los montos de su presupuesto. Los grandes números quedaron divididos de la siguiente forma: 6932 millones de pesos para los gastos de operación del IFE (53.6\% del presupuesto), 4926 para el financiamiento de los partidos políticos (38.1\%), y 1162 millones de pesos para el voto de los mexicanos en el extranjero $(8.2 \%)^{22}$. La fórmula de financiamiento público de los partidos tiene varios componentes, pero dos de los más importantes son que en años electorales la suma de los partidos se multiplica por dos y se entregan dos bolsas de igual monto: una para gastos ordinarios y otra para la campaña. La otra es que la fórmula crece de acuerdo con el número de partidos políticos con registro, así que con este factor se hace un barril sin fondo de dinero público. De esta forma, la cantidad de las ministraciones para los partidos quedó en dos grandes sumas, cada una por un monto de más de 2133 millones de pesos. Se estima que de 2000 a 2006 hubo un incremento de 55\% en relación con el gasto de los partidos en las campañas.

Junto con el presupuesto se establecen los topes financieros para cada tipo de campaña. Para 2006 quedó establecido que la campaña para diputados fuera de 976 mil pesos, la de senador de un millón 974 mil pesos, y la de presidente de 632 millones de pesos, lo cual daría un monto de mil 462 millones de pesos 23 .

\footnotetext{
se conoció como "ley Televisa" fue apoyada mayoritariamente por el PAN en el Congreso de la Unión. Algunas de sus características más negativas son una regulación débil, un reparto inequitativo y concentrador del espacio radioeléctrico y una exclusión de las radios comunitarias, entre otras graves deficiencias.

22 IFE, Acta del Consejo General, 18 de agosto de 2005.

23 Para el cálculo de las bolsas de financiamiento se sigue un procedi-
} 
Cuadro 1. Financiamiento público de los partidos políticos 1997-2007 (millones de pesos)

\begin{tabular}{c|c|c|c|c}
\hline 1997 & 2000 & 2003 & 2006 & $2007^{\star}$ \\
\hline 2111 & 3064 & 4937 & 4926 & 2633 \\
\hline
\end{tabular}

FUENTE: Dirección de prerrogativas y partidos políticos del IFE.

* Para 2007 se trata de un cálculo preliminar. En 2007 sólo será 50\% de los otros años, si fuera año electoral serían 5266 millones de pesos. Reforma, 27 de octubre de 2006.

Esta danza de millones, que con la reforma de 1996 logró las condiciones de equidad en la competencia, empezó a generar conflictos a partir del año 2000, en el cual se registraron dos grandes expedientes de financiamiento ilegal: Pemexgate y Amigos de Fox. Para 2003 fue escandaloso el monto, porque la bolsa se incrementó por la cantidad de partidos nuevos que llegaron a la escena política, los cuales, en su gran mayoría, no pasaron de ser jugosos negocios familiares. Por ello, el monto de 2003 fue similar al del año 2000, a pesar de que sólo se trató de una elección intermedia para diputados federales, es decir, en lugar de tres elecciones sólo hubo una, pero con un ción creció hasta llegar a $60 \%$. Lo que hubo entonces fue la elección más costosa y abstencionista de la historia contemporánea del país.

La otra parte del modelo tiene que ver con el destino de los gastos. ¿A dónde va a parar este dinero público? La respuesta es simple: la mayor parte a los medios masivos. El modelo de campañas electorales completamente mediáticas es una realidad contundente. La lógica de estar todo el tiempo con presencia en los medios y, sobre todo, en televisión, que es el más costoso, en campañas demasiado largas y sin ningún arbitraje consistente, genera una situación como la que hubo en 2006.

miento de tres pasos: primero se calcula el costo mínimo de una campaña de diputado y se multiplica por 500 y por el número de partidos con registro, en este caso, por 8; luego, la bolsa se distribuye de forma compuesta: $30 \%$ de forma igualitaria y $70 \%$ de forma proporcional al resultado de cada partido en las elecciones anteriores; de la misma forma se reparte $2 \%$ de la bolsa a los partidos que obtuvieron su registro en fecha posterior a la última elección federal, en este caso hubo dos partidos nuevos, Alternativa y el Panal, los cuales recibieron una bolsa de 82 millones multiplicada por dos, actividades ordinarias y campañas; y el tercer paso es la multiplicación por dos en años electorales.
En los informes preliminares del gasto en medios, los partidos y candidatos establecieron un rango de gastos de entre $63 \%$ y $74 \%$, como se puede ver en el cuadro 2 (p. 31 ), por si quedaba alguna duda de a dónde va el gasto y quién es el ganador de estas inversiones millonarias. Por eso se puede hablar de la complementación de un modelo firmemente unido: política electoral + financiamiento público = campañas en medios masivos.

Una de las formas de saber cómo se desarrolla la competencia electoral es a través de los monitoreos de medios que se realizan durante las campañas electorales. A diferencia de elecciones anteriores, en esta ocasión el IFE decidió que el monitoreo lo hiciera la empresa IBOPE, una trasnacional de origen brasileño especializada en medición de audiencias. Cuando se tiene acceso a la información se puede ver que el universo del muestreo se hizo sobre 206 noticieros de radio y 123 de televisión. A pesar de que se pueden tener datos para la fiscalización, este tipo de medición presenta problemas que el Comité Conciudadano de Observación del Proceso Electoral estableció: los derechos de propiedad y las bases de datos están a favor de IBOPE y no del IFE, que pagó; no se tiene acceso a las tablas de datos, sólo se pueden ver datos agregados, con una sola variable por región; no se puede verificar la veracidad de la información; se puede tener un monitoreo, pero la forma de consulta es demasiado estrecha para establecer algún tipo de análisis más allá de los datos agregados ${ }^{24}$.

\footnotetext{
${ }^{24}$ Comité Conciudadano, segundo balance, 21 de junio de 2006. Por ejemplo, sobre los datos del IBOPE, en un cuadro sobre los anuncios promocionales de televisión que mide la campaña, entre el 19 de enero y el 28 de junio, se dice que el PAN lanzó 37603 promocionales; Alianza por México, 60 224, y la Coalición, 29 923; a su vez, se mide en se-
} 
Cuadro 2. Gasto en medios masivos de los tres principales candidatos a la presidencia en 2006

\begin{tabular}{c|c|c}
\hline Partido & Monto (pesos) & \% del tope de campaña \\
\hline PAN & $433772344^{\star}$ & 74 \\
\hline Alianza por México & $444844809^{\star *}$ & 63 \\
\hline CPBT & $402841593{ }^{* * *}$ & 60 \\
\hline
\end{tabular}

FUENTE: Informes especiales de gastos aplicados a la campaña presidencial, <www.ife.org.mx $>$.

* Acumulado al 31 de julio. $\quad{ }^{* *}$ Acumulado al 26 de julio. $\quad{ }^{* * *}$ Acumulado al 31 de junio.

El modelo de un financiamiento excesivo de campañas, el esquema de acceso a medios (por contratación libre de partidos y candidatos) y la larga duración producen campañas como la de 2006: plagadas de propaganda sucia, sin debate político — salvo los dos pequeños momentos de los debates que, con tantas reglas de protección, en ningún momento se da un debate real-, campañas completamente mediáticas, en las cuales la ciudadanía es el receptor pasivo de mensajes que generan filias, fobias $y$, por supuesto, una gran polarización social.

\section{¿QUÉ ELEGIR EN 2006?}

El juego de la política real dejaba un escenario en el cual la clase política se encargó de lastimar el prestigio que tenía y, sobre todo, de demostrar que en el juego no había blancos y negros, sino una gama de grises. La elección entre Calderón y López Obrador tendría sólo acentos, porque cuando le quitamos el drama a los discursos de campaña quedan los pequeños márgenes de maniobra que tendría el próximo presidente, independientemente de su color ideológico. Como en otras democracias, no se trataba de proyectos fundacionales, sino de un rango de políticas públicas, como veremos a continuación.

El escenario electoral de 2006 se puede entender desde la evolución de un dilema: en el año 2000 la principal

gundos cada uno de estos rubros y se establece cuántos se transmitieron en horario estelar y en horario regular, y cuántos a nivel nacional y cuántos a nivel local. En los promocionales de los candidatos en el mismo periodo destaca Calderón con 11904 (2 474 en horario estelar); Madrazo con 10425 ( 1514 en horario estelar); y López Obrador con 16316 (2 271 en horario estelar). interrogante del voto giraba en torno al eje de más de lo mismo - un triunfo del PRI- o un cambio y un voto por la alternancia. En 2006 la decisión era más complicada porque supera el dilema de por quién votar y se instala en el desafío de qué votar, por cuál proyecto. Así, mientras en 2000 la lógica fue de referéndum, seis años después la lógica de construcción política consiste en un referéndum más complicado: continuidad del PAN y del sexenio foxista, o un giro hacia un nuevo cambio, con el PRD. Una opción de una sola variable frente a una multivariada.

Estábamos ante la opción de elegir entre un proyecto de corte liberal de derecha o hacia un proyecto popular de izquierda. El espectro político se ha decantado en la disputa por el centro, el panismo con el centro derecha y el perredismo con el centro izquierda. El tercero en la pelea se rezagó: el PRI dejó de jugar como parte del eje de la lucha por el poder, entre otras cosas porque su candidato no pudo salir del tercer lugar en el que se ubicó desde el inicio de la contienda. A pesar de que el PRI se quiso ubicar al centro del espectro político, las bajas expectativas de triunfo y la medición de las intenciones del voto no lo reconocieron como parte del debate central y polar entre PAN y PRD; en 2006 el PRI fue el tercero excluido en términos de la presidencia de la República ${ }^{25}$.

La elección de 2006 se puede entender desde el supuesto de un voto dividido que se volverá a desdoblar en dos rutas diferentes: la de la presidencia y la del Congreso.

\footnotetext{
${ }^{25}$ De acuerdo con un estudio de Alejandro Moreno (2006: 57), se indica que: "Entre el panista y el perredista se reparten casi $80 \%$ del electorado de centro, del cual $42 \%$ respalda a AMLO y $36 \%$ a Felipe Calderón. El restante 22\% de los centristas favorece a Roberto Madrazo".
} 
Mientras en la primera se jugará con un amplio voto volátil que apoyará la opción ganadora, en el poder legislativo dominará más el voto por el partido, por lo que, de nuevo, el presidente no tendrá mayoría legislativa, como lo veremos más adelante. Según datos de mayo de 2006, la intención del voto por un mismo partido entre presidencia y congreso sólo era de $56 \%$, y el voto diferente era de $31 \%$, por ello las diferencias en la intención del voto entre diputados y presidencia. Así, Calderón tenía a principios de mayo una intención de 35\% y los diputados del PAN de 38\%; Madrazo, 27\%, y el PRI, 33\%: en ambos casos el partido por encima del candidato. En cambio, López Obrador tenía 34\% y el PRD sólo 26\%26. Hay certezas y zonas de incertidumbre sobre las ofertas de los candidatos que se disputan la presidencia. El candidato del PRD ha seguido la estrategia de presentar una plataforma básica de un documento que dio a conocer en julio de 2005, denominado "Cincuenta compromisos para recuperar el orgullo nacional", y luego, durante la campaña electoral, hizo adaptaciones para cada entidad federativa en las que adecuó la estructura general y estadesde una política social y sus planes de austeridad con la burocracia, hasta los instrumentos para generar crecimiento económico y empleo. La base de estas propuestas se encuentran en un libro que el candidato publicó desde antes de salir de la jefatura del gobierno del Distrito Federal — Un proyecto alternativo de nación —, en el cual estableció veinte planteamientos para perfilar su proyecto de país (López Obrador, 2004).

Por su parte, Calderón presentó un documento de campaña en el que desarrolló cinco grandes ejes: estado de derecho y seguridad pública; economía competitiva y generadora de empleos; igualdad de oportunidades; desarrollo sustentable y democracia efectiva; y política exterior responsable.

Desde la lógica que decanta el perfil ideológico de los ciudadanos se establece que el votante por López Obrador es socialmente liberal, preocupado por la redistribu-

\footnotetext{
${ }^{26}$ Datos de la encuesta de Consulta Mitofsky, Así van ..., abril de 2006, presentada el 3 de mayo de 2006 en el noticiero de Joaquín López Dóriga, en el canal 2 de Televisa.
}

ción económica y la responsabilidad social del Estado. En cambio, el votante por Calderón es de derecha económica, mercado y libre empresa, con incentivos al desarrollo capitalista y conservador en temas sociales (Moreno, 2006: 58). En estos perfiles ideológicos también existen grados de intensidad que se destacan como duros o blandos, los cuales forman áreas de mayor interés en las distinciones de los ejes señalados: por ejemplo, más o menos Estado; mayor o menor regulación estatal; amplia o restringida responsabilidad social del Estado. Existen otras partes, problemáticas valorativas y morales que polarizan a liberales y conservadores en temas como el aborto, la píldora del día siguiente, los matrimonios homosexuales o la posición frente a enfermos del sida.

López Obrador era un candidato que se presentaba más cercano a un gobierno redistributivo, que ofreció apoyo social a grupos de bajos ingresos, como pensión alimentaria para adultos mayores, educación pública gratuita, desayunos y útiles escolares; también planteó modernizar el sector energético sin privatizar y compromisos explícitos para no cobrar el impuesto al valor agregado (IVA) en alimentos y medicinas, así como reducir los salarios de la alta burocracia y desaparecer las pensiones a los ex presidentes, entre otros muchos.

Por su parte, Calderón presentaba un proyecto más inclinado a la competitividad de la economía y al empleo, y su propuesta de política social se ubicaba en la generación de oportunidades. El panista insistía en presentar un gobierno que cumpliera e hiciera cumplir la ley, propuesta que lo ubicaba con una mayor preocupación por el estado de derecho. En esta línea de propuestas no había nada sobre la autonomía de las instituciones de Estado o la de los poderes, legislativo y judicial, como sí las hizo el candidato de la Coalición por el Bien de Todos.

Los dos candidatos construyeron estereotipos para una identificación electoral: López Obrador resaltó dos aspectos: la preocupación por los pobres y el carácter de alternativa frente al actual gobierno, lo que mantuvo durante toda la campaña. Calderón enfatizó primero una imagen fuerte sobre la legalidad, pero como no funcionó para el crecimiento en las intenciones del voto, hizo un giro para presentarse como el presidente del empleo.

La construcción de expectativas era como una respues- 


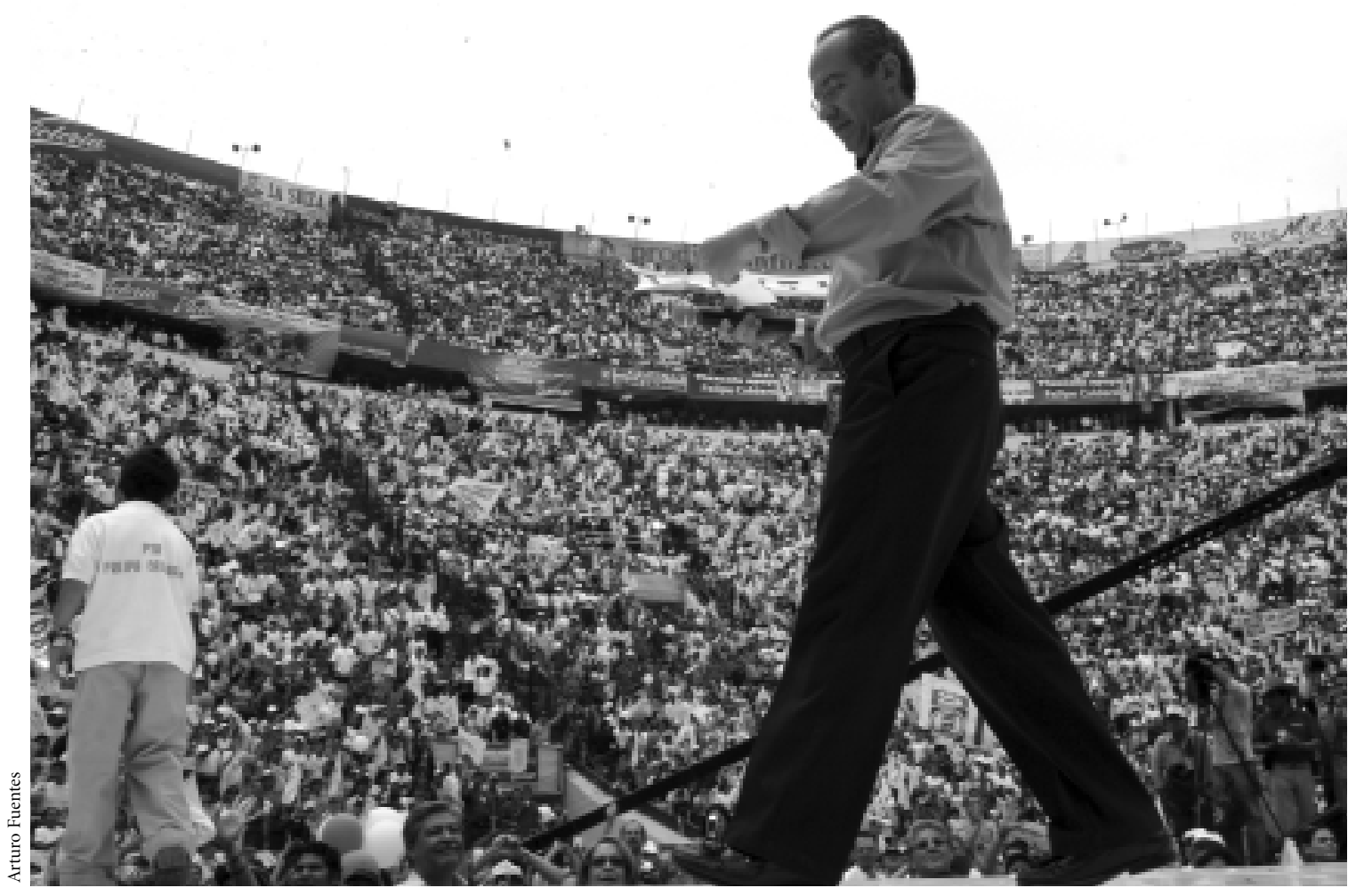

Felipe Calderón, durante su campaña presidencial.

ta a las propuestas de los candidatos. En una encuesta se preguntó a los ciudadanos con qué palabra identificaban a los candidatos y el resultado fue que para Calderón la palabra era 'desarrollo'; en cambio, para López Obrador fue 'esperanza'27. Calderón hizo el núcleo de su propuesta en torno a la competitividad y el eficientismo; para López Obrador, su jerarquía de prioridades era la distribución y la austeridad. Para Calderón, el reto económico más importante era la falta de competitividad y la incapacidad para crear empleos; para López Obrador, la falta de crecimiento económico. El rasgo distintivo de Calderón sería la competitividad y el desarrollo humano; López Obrador proponía el combate a la pobreza y a la corrupción (véase Aristegui, 2006).

\footnotetext{
27 Consulta Mitofsky, op. cit.
}

En la lógica del panista se trata de realizar las reformas que hacían falta (laboral, energética, fiscal, política); al mismo tiempo se proponía continuar con las políticas de estabilidad económica que han caracterizado a los últimos dos gobiernos federales - Zedillo y Fox - y seguir con la actual política social, para lo que se fortalecería el programa Oportunidades y el Seguro Popular. Calderón retoma en su propuesta los indicadores internacionales para establecer algunos compromisos, sobre todo en la reducción de la pobreza, dentro de los tres criterios que se manejaron en el gobierno foxista (pobreza alimentaria, de capacidades y de patrimonio ${ }^{28}$. El discurso panista

\footnotetext{
${ }^{28}$ La pobreza alimentaria llegó a 17.3\% en 2004: la idea es que para 2012 se ubique entre 10 y $5 \%$; la pobreza de capacidades, que llegó a 24.6\% en 2004, se bajaría a 13\%; y la pobreza patrimonial, que llegó a 47\%, bajaría a 34\%. Cuestionario Diálogos por México, programas de entrevista a los candidatos a la presidencia organizados por la empresa Televisa.
} 
está más ubicado en el juego internacional, en la medición de los indicadores de desarrollo, competencia, corrupción y transparencia; en cambio, el discurso de López Obrador es más de corte valorativo, apela al "deber ser" de un Estado que no ha cumplido con su responsabilidad social; tiene un tinte más ideológico en las referencias juaristas. Calderón es más pragmático y eficientista. Sin embargo, en términos de moral y de cultura los papeles se invierten, como quedó asentado en las entrevistas que hizo a los candidatos, durante las primeras semanas de la campaña, el periodista Joaquín López Dóriga en el noticiero del canal 2 sobre temas como el aborto o la píldora del día siguiente, en los cuales López Obrador y Calderón contrastaron por sus respuestas y el universo de la díada entre izquierda y derecha se desplazó hacia el horizonte del eje liberal-conservador: el perredista respondió como un liberal y el panista como un conservador.

Mientras López Obrador quería recuperar el Estado de bienestar, Calderón proponía hacer más competitivo al país. En suma, los dos proyectos a elegir en 2006 tenían los rasgos y las preocupaciones que suelen tener la izquier-

da y la derecha en otros países. En la izquierda hay una sensibilidad por los temas de la desigualdad y el combate a la pobreza, un Estado más solidario que pueda intervenir más para generar equilibrios sociales y hacerse cargo de los grupos más vulnerables. En cambio, en el lado de la derecha, las preocupaciones son más hacia el desarrollo individual, la profundización de la economía de mercado en términos de eficiencia y productividad, para lo que se necesita un Estado más eficiente para acompañar estos objetivos. En términos de proyectos de país, la elección de 2006 sería entre un proyecto de más competitividad frente a otro de mayor distribución.

\section{VOTOSY ESCAÑOS}

Después de una jornada electoral que transcurrió de acuerdo con el libreto, se hizo realidad el peor escenario: la incertidumbre sobre el ganador. Las encuestas de salida anticiparon un resultado completamente empatado. Las televisoras decidieron no dar a conocer el resultado de sus encuestas por lo cerrado de los números. El conteo rápido del IFE tampoco pudo definir un ganador, porque la diferencia entre los dos punteros supuestamente no permitía marcar una tendencia cierta. Ese largo 2 de julio el país terminó sin un ganador, pero los dos punteros se declararon vencedores.

El Programa de Resultados Electorales Preliminares (PREP) dio información sobre $98.45 \%$ ciento de las actas de casilla para elegir presidente de la República, 98.37\% para senadores y $98.32 \%$ para diputados. El PREP funcionó entre las 20:00 horas del 2 de julio y las 20:00 del 3 de julio $^{29}$. La diferencia entre Calderón y López Obrador fue de $0.62 \%$ en favor del panista. El IFE estableció que, para saber el resultado, habría que esperar el cómputo distrital, que se iniciaría el miércoles siguiente a la elección. Sin embargo, desde las primeras expresiones del candidato perdedor quedó establecido que la elección terminaría en el Tribunal Electoral, que calificaría el proceso una vez resueltas las impugnaciones, lo que representaba llegar hasta la primera semana de septiembre — dos meses después del 2 de julio- para saber quién era el ganador.

En un ejercicio maratónico que se inició el día 5 de julio por la mañana y concluyó en las primeras horas del día siguiente, quedó establecido que había una gran similitud entre los datos del PREP y los del cómputo distrital, como se puede apreciar en el cuadro 3 (p. 35). También se puede ver que la mayoría de los candidatos suben en su votación absoluta del PREP al cómputo distrital, salvo el PRI y Alternativa, que tienen una pequeña baja.

Sin duda, el problema de la sospecha de fraude era que, en un universo de 41 millones 791 votantes, la diferencia entre Calderón y López Obrador era de sólo 243934 sufragios. La otra duda era que en los procedimientos de recuento, la diferencia entre los dos punteros era menor. En el PREP, sin las casillas con inconsistencias, había un poco más de un punto porcentual de diferencia; luego, con $98.37 \%$ de las casillas del PREP, la distancia se redujo a 263 mil votos (0.62\%), y cuando terminó el cómputo distrital, la diferencia quedó en sólo $0.58 \%$. Con esta pequeña diferencia se produjo la principal consigna del movimiento que respaldaba a López Obrador: se pedía al TEPJF

${ }^{29}$ Véase el documento "Informe final del Comité Técnico Asesor del PREP”, 31 de agosto de 2006. 
Cuadro 3. Comparación nacional PREP 2006 y cómputos distritales

\begin{tabular}{|c|c|c|c|c|c|}
\hline \multicolumn{6}{|c|}{ Votación nacional para la elección de presidente } \\
\hline Partido político o coalición & PREP 2006 & $\%$ & Cómputos distritales & $\%$ & Diferencia de \% \\
\hline PAN & 14771009 & 35.91 & 15000284 & 35.89 & 0.02 \\
\hline APM & 9127889 & 22.19 & 9031441 & 22.26 & -0.07 \\
\hline СРВТ & 14513477 & 35.29 & 14756350 & 35.31 & -0.02 \\
\hline Nueva Alianza & 398263 & 0.97 & 401804 & 0.96 & 0.01 \\
\hline Alternativa & 1114006 & 2.71 & 1128850 & 2.70 & 0.01 \\
\hline No registrados & 296164 & 0.72 & 297989 & 0.71 & 0.01 \\
\hline Nulos & 909769 & 2.21 & 904604 & 2.16 & 0.05 \\
\hline Total & 41130577 & 100.0 & 41791322 & 99.99 & \\
\hline Actas & 128771 & & 130488 & & \\
\hline
\end{tabular}

FUENTE: Informe final del Comité Técnico Asesor del PREP 2006.

que hiciera un recuento total de la elección, con el argumento de que el fraude había cambiado el resultado; así surgió la consigna: "voto por voto, casilla por casilla". Esta demanda corrió de forma paralela al expediente jurídico de impugnación. Como veremos, entre el expediente jurídico y el movimiento político no hubo coherencia. Jugar en una democracia implica una aceptación de las reglas, porque éstas se aceptan sólo de forma parcial se tiene una participación conflictiva, que fue lo que sucedió con la crisis poselectoral a la que llevó el resultado de una diferencia mínima entre los punteros.

Los resultados de la elección dejaron un mapa electoral diferente al que se había dado en las elecciones federales del año 2000 y en el Congreso también se modificaron las tendencias. Para analizar los datos organizamos cuatro criterios: la geografía de cómo votaron los estados, la composición del Congreso de la Unión, el voto diferenciado por tipo de elección y los niveles de participación ciudadana en las urnas.

\section{Una nueva geografía electoral}

En la elección presidencial el país votó de forma dividida: el PAN ganó 16 estados: Aguascalientes, Baja Califor- nia, Coahuila, Colima, Chihuahua, Durango, Guanajuato, Jalisco, Nuevo León, Puebla, Querétaro, San Luis Potosí, Sinaloa, Sonora, Tamaulipas y Yucatán; y la Coalición por el Bien de Todos, el Distrito Federal más los otros 15 estados: Baja California Sur, Campeche, Chiapas, Guerrero, Hidalgo, Michoacán, Morelos, Nayarit, Oaxaca, Quintana Roo, Tabasco, Tlaxcala, Veracruz y Zacatecas. El PRI no ganó en ningún estado.

Esta nueva distribución geográfica de los votos también tuvo su expresión en las elecciones legislativas, que fueron concurrentes a la elección presidencial, con lo que se modificaron las tendencias que se habían mantenido hasta 2003. Desde que se generalizó la competencia electoral entre las tres fuerzas políticas principales ${ }^{30}$, los formatos de partido se ubican mayoritariamente en dos sistemas bipartidistas: PRI-PRD y PRI-PAN, con una franja de multipartidismo que crece en elecciones presi-

\footnotetext{
${ }^{30}$ Una forma de medir la competencia electoral es mediante un esquema de formalización que se hace con base en las elecciones federales de diputados. Para ello se establece un formato de partidos con base en rangos de votación. A partir de 1994 desaparecen los formatos de partido dominante y único, y el sistema entra en un acelerado proceso de competitividad que se ubica, a partir de las elecciones intermedias de 1997, en formatos de competencia bipartidista y multipartidista, como se muestra en el cuadro sobre el formato de elecciones.
} 
denciales y decrece en elecciones intermedias. Entre las elecciones de 2000 y las de 2006, tanto el PRD como el PAN logran tener bastiones con una amplia mayoría, el primero en Tabasco y el Distrito Federal, el segundo en Guanajuato y Querétaro. El bipartidismo PAN-PRI se manifestó en 17 estados del país (la mitad del territorio nacional); en cambio, PRI-PRD sólo cubrió dos estados. En 2006 el bipartidismo PAN-PRI bajó y se dio sólo en trece estados, y PRD-PRI subió a cuatro estados, cuya distribución territorial apunta a un norte y centro-occidente blanquiazul, y a un centro y sur amarillo. El PRI pasa a ocupar el tercer lugar, con un nuevo tamaño de $22 \%$ en las elecciones presidenciales y $28 \%$ en las elecciones de diputados federales. Una novedad de 2006, que se expresó con mucha nitidez en la elección presidencial, fue la división del país entre PAN y PRD, pero en las elecciones de diputados hay un bipartidismo entre esos dos partidos que antes no existía, como en el caso del estado de Tlaxcala.

A continuación presentamos de manera más gráfica cómo se da la distribución de los formatos electorales, a partir del ejercicio que hemos mantenido desde 1985, con el objetivo de medir y ponderar los avances en la competitividad electoral mediante el seguimiento de un indicador: las elecciones de diputados federales. Vale la pena aclarar que, a pesar de tratarse de una variable de elección — diputados federales—, existe un comportamiento diferencial que depende del tipo de elección: cuando se trata de comicios presidenciales, el voto se comporta de distinta manera que cuando es una elección intermedia.

Sólo para ejemplificar hicimos la comparación entre dos elecciones presidenciales: la del año 2000 y la de 2006, y encontramos los siguientes resultados: crece la presencia competitiva del PRD tanto en los formatos bipartidistas como en los multipartidistas, lo cual obedece a la presencia de un candidato a la presidencia que impulsa de forma importante, al grado de elevar la votación en más 8 millones 497 mil sufragios respecto a lo que obtuvo la Alianza por México, que apoyó a Cuauhtémoc Cárdenas en 2000, y la Coalición por el Bien de Todos, que apoyó a López Obrador, lo cual representó más de $18.67 \%$ en seis años. Sin duda, este fue el fenómeno más importante en términos de crecimiento electoral para un partido y su candidato a la presidencia. Desde este mirador, el PAN, que ganó en 2006, lo hizo a la baja, porque en 2000 sumó $42.52 \%$ de los votos, que en términos absolutos fueron 15 millones 988 mil votos; en cambio, Calderón se quedó por debajo de los 15 millones en el resultado final y con una baja porcentual de 6.65\%. Para el PRI, la derrota en 2000 lo llevó al segundo lugar con $36.10 \%$ de los votos, pero en 2006 se fue al tercer sitio con $22.26 \%$, perdió $13.84 \%$ y 4 millones 545 mil sufragios, una severa derrota.

\section{El voto diferenciado}

Como en otras elecciones, ahora volvió a darse el voto cruzado. Entre los tres grandes partidos hubo diferencias; la más notoria fue la del mismo PRI, en el cual sus diputados y senadores están seis puntos arriba de su candidato presidencial, lo cual implica que se ejerció la segunda opción del voto de los priístas entre PRD y PAN. La diferencia entre López Obrador y los candidatos a legisladores de su partido es inversamente proporcional a la del PRI, ya que el candidato a la presidencia del PRD está seis puntos arriba; en el PAN también hubo una diferencia, pero menor, ya que su candidato presidencial quedó sólo dos puntos arriba de los candidatos a diputados y senadores.

En los partidos nuevos también hubo un voto diferenciado; por ejemplo, el más evidente y voluminoso fue el caso del Partido Nueva Alianza, en el cual sus diputados tienen $4.5 \%$ y sus senadores $4 \%$, mientras su candidato a la presidencia sólo obtiene $0.96 \%$, es decir, más de tres puntos de diferencia, lo cual implica que hay un millón y medio de votos que fueron para los diputados y senadores, pero no para Roberto Campa. Aquí se especula que una buena cantidad de estos votos fueron para Calderón, aunque también se ha demostrado que hubo votos para López Obrador.

En cambio, el efecto fue inverso en el partido Alternativa porque Mercado logró un millón 128 mil votos, pero sus candidatos al Congreso obtuvieron entre 340 y 280 mil votos menos para senadores y diputados respectivamente. Ese diferencial probablemente fue a dar a otros partidos.

En una encuesta de salida que se hizo el día de la elección a siete mil personas, con un error muestral de $\pm 1.2 \%$ 
Cuadro 4. Formato del sistema de partidos políticos en elecciones de diputados federales en México, clasificación por estados, 2000-2006

\begin{tabular}{|c|c|c|}
\hline Tipo & 2000 presidencial & 2006 presidencial \\
\hline & 0 & 0 \\
\hline \multirow{2}{*}{$\begin{array}{l}\text { SPDC } \\
\text { Sistema de partido dominante } \\
\text { (entre } 50 \text { y } 59.9 \% \text { del voto) }\end{array}$} & $\begin{array}{l}\text { Nayarit y Sinaloa, PRI } \\
\text { Guanajuato, PAN }\end{array}$ & $\begin{array}{l}\text { Distrito Federal y Tabasco, PRD } \\
\text { Guanajuato y Querétaro*, PAN }\end{array}$ \\
\hline & 3 & 4 \\
\hline \multirow[t]{2}{*}{$\begin{array}{l}\text { SB } \\
\text { Sistema bipartidista } \\
\text { (diferencia entre } 1^{\circ} \text { y } 2^{\circ} \text { lugar } \\
\text { menor a } 20 \%)\end{array}$} & $\begin{array}{l}\text { Entre PRI y PAN: } \\
\text { Baja California, Colima, Jalisco, Sonora, } \\
\text { Aguascalientes, Coahuila, Chihuahua, } \\
\text { Durango, Nuevo León, Querétaro, San Luis } \\
\text { Potosí, Tamaulipas, Campeche, Yucatán, } \\
\text { Hidalgo, Morelos, Puebla, } 17 \\
\text { Entre PRI y PRD: } \\
\text { Tabasco, Guerrero, } 2\end{array}$ & $\begin{array}{l}\text { Entre PAN y PRD: } \\
\text { Tlaxcala, } 1 \\
\text { Entre PAN y PRI: } \\
\text { Aguascalientes, Baja California, Coahuila, } \\
\text { Colima, Chihuahua, Durango, Jalisco, Nuevo } \\
\text { León, San Luis Potosí, Sinaloa, Sonora, } \\
\text { Tamaulipas y Yucatán, } 13 \\
\text { Entre PRD y PRI: } \\
\text { Chiapas, Guerrero }^{\star *} \text {, Nayarit, Oaxaca, } 4\end{array}$ \\
\hline & 19 & 18 \\
\hline \multirow[t]{2}{*}{$\begin{array}{l}\text { SM } \\
\text { Sistema multipartidista } \\
\text { (diferencia entre } 1^{\circ}, 2^{\circ} \text { y } 3^{\text {er }} \\
\text { lugar menor a } 20 \%)\end{array}$} & $\begin{array}{l}\text { Baja California Sur, Zacatecas, Chiapas, } \\
\text { Oaxaca, Quintana Roo, Veracruz, Distrito } \\
\text { Federal, Tlaxcala, Michoacán, México } \\
\text { (PRI, PAN y PRD) }\end{array}$ & $\begin{array}{l}\text { Campeche, Hidalgo, México, Michoacán, } \\
\text { Morelos, Baja California Sur, Puebla, Quintana } \\
\text { Roo, Veracruz, Zacatecas } \\
\text { (PAN, PRD y PRI) }\end{array}$ \\
\hline & 10 & 10 \\
\hline
\end{tabular}

FUENTE: Elaboración propia con base en resultados de elecciones federales de diputados de mayoría relativa.

* Querétaro en 2006: el PAN tuvo 48.15\% y el segundo lugar estuvo 23\% abajo.

** Guerrero en 2006: el PRD tuvo 46.4\%, pero el segundo lugar tuvo 30\%.

y un nivel de confiabilidad de 95\%, se pudo observar que del total que votó por el PRI para diputados federales, $11.6 \%$ lo hizo por Calderón; de los que votaron por el PRD para diputados, $4.8 \%$ lo hizo por el candidato panista, lo cual implica 600 mil votos; en el caso de Nueva Alianza, de su millón 800 mil votos para diputados, 30\% lo hizo por el PAN a la presidencia, lo que implica unos 600 mil votos; por último, en el caso de Alternativa, que tuvo casi 850 mil votos para diputados, $11.6 \%$ votó por el panista, lo cual representa unos 100 mil votos ${ }^{31}$. En otra encuesta de salida se hizo otra aproximación para ver cómo se repartieron los votos de Nueva Alianza: López Obrador y Campa son los que más sufragios recibie-

\footnotetext{
${ }^{31}$ Encuesta de Parametría, en Excélsior, 14 de julio de 2006.
}

ron, con 28\%, y Calderón con 23\%. En esta medición también se destaca que en los estados donde ganó Calderón contó con el voto del Panal, de la misma forma que López Obrador contó con esos sufragios en la parte del país que ganó ${ }^{32}$.

Sin duda, uno de los actores que jugó, ganó e hizo perder al PRI en 2006 fue el factor Gordillo. Una vez pasadas las elecciones, Gordillo hizo público su propio balance en los siguientes términos: Madrazo "no ganó en una sola de las entidades federativas, incluyendo Tabasco, su estado natal, en donde lo conocen muy bien. De 64 posiciones de mayoría en el Senado, el PRI ganó ocho; de 300 diputaciones de mayoría, el PRI ganó 62; ninguna de las

\footnotetext{
${ }^{32}$ La Revista de El Universal, semana del 24 al 30 de julio de 2006.
} 
Cuadro 5. Integración del Congreso de la Unión LX Legislatura / Cámara de Diputados

\begin{tabular}{l|c|c|c}
\hline Partido & Diputados RP & Diputados MR & Total \\
\hline PRI & 41 & 63 & 104 \\
\hline PVEM & 17 & 2 & 19 \\
\hline PAN & 69 & 137 & 206 \\
\hline PRD & 36 & 90 & 126 \\
\hline PT & 13 & 3 & 16 \\
\hline Convergencia & 11 & 5 & 16 \\
\hline Panal & 9 & 0 & 9 \\
\hline PASC & 4 & 0 & 4 \\
\hline Total & 200 & 300 & 500 \\
\hline
\end{tabular}

FUENTE: Registro ante el IFE.

gubernaturas en juego [...]. Me siento muy satisfecha de haber servido a México: Roberto Madrazo nunca será presidente de la República"33.

\section{El poder legislativo}

El Congreso tendrá una nueva composición; seguiremos con un gobierno dividido, las cámaras tendrán tres fracciones y la diferencia en la composición de los grupos parlamentarios será cercana. Por ejemplo, entre el primero (PAN) y el segundo lugar (CPBT) hay sólo una diferencia de $4.4 \%$ en la Cámara de Diputados; y entre el segundo y el tercer lugar (APM) habrá sólo $0.7 \%$ de distancia. Por supuesto que estos números se fragmentarán a la hora de hacer la distribución en las dos coaliciones y habrá nuevas coaliciones legislativas.

La novedad sobre las posibles alianzas es que la Coalición por el Bien de Todos transitó hacia la formación de un Frente Amplio Progresista (FAP), que mantendrá unidos a los tres partidos e incorporará a otras organizaciones, con el objetivo de presentar una agenda legislati-

\footnotetext{
${ }^{33}$ Desplegado en El Universal, 15 de julio de 2006.
}

Cuadro 6. Integración del Congreso de la Unión LX Legislatura / Cámara de Senadores

\begin{tabular}{l|c|c|c}
\hline Partido & Senadores $R P$ & Senadores MR & Total \\
\hline PRI & 6 & 27 & 33 \\
\hline PVEM & 4 & 2 & 6 \\
\hline PAN & 11 & 41 & 52 \\
\hline PRD & 6 & 23 & 29 \\
\hline PT & 2 & 0 & 2 \\
\hline Convergencia & 2 & 3 & 5 \\
\hline Panal & 1 & 0 & 1 \\
\hline PASC & 0 & 0 & 0 \\
\hline Total & 32 & 96 & 128 \\
\hline
\end{tabular}

FUENTE: Registro ante el IFE.

va común. Por otra parte, hay señales de que habrá una alianza legislativa de carácter más permanente entre el PAN y el PRI, con lo cual se tendrán dos coaliciones legislativas en la LX Legislatura. Los partidos pequeños tendrán la movilidad de su propia agenda, lo cual los llevará a oscilar entre las dos grandes coaliciones parlamentarias.

\section{Participación}

Según los datos del IFE, la Lista Nominal de Electores era de 71350976 ciudadanos, lo cual equivale a 91.9\% de ciudadanos con credencial como porcentaje de la población mayor de edad. Sobre esa base, la participación electoral fue de $58.55 \%$, con los altibajos que muestran los índices por estado, en donde los más altos fueron Tabasco, con $68.22 \%$, y el Distrito Federal, con más de $68.05 \%$, y en la parte más baja quedaron Guerrero, con $46.47 \%$, y Baja California, con $46.97 \%$. Si comparamos estos resultados con los del año 2000, la participación bajó 5.4\%; pero si se compara con el año de 2003, hay una recuperación importante, a pesar de que las campañas de guerra sucia generalmente alejan a los ciudadanos de las urnas porque en las elecciones intermedias sólo votó $41.8 \%$, por lo que aumentó la participación en $16.7 \%$. 
Si Fox tuvo 42\% y un gobierno dividido, Calderón sólo tendrá $35 \%$, menor margen y un escenario más complejo. El nuevo mapa electoral anunció la permanencia de otro gobierno sin mayoría legislativa. En cualquier hipótesis, un presidente con $35 \%$ de los votos y un congreso partido en tres fracciones resulta un complicado mundo para construir acuerdos.

Una forma de evaluar el nivel de participación es ver la tendencia que se presenta desde las elecciones presidenciales del año 2000, en las cuales se da una baja, no sólo en los comicios estatales, sino en los federales. Si se mira únicamente la subida de la participación entre las elecciones intermedias de 2003 y la presidencial de 2006, se tendrá sólo un supuesto parcial, porque hay que comparar según el tipo de elección. Así se ve la caída en 2003 respecto a 1997, y al comparar 2000 con 2006, sucede lo mismo. Por otra parte, cuando se trata de asociar el fenómeno de la participación con razones explicativas, entra en juego un conjunto de valores políticos importantes.

Si en 2006 la participación bajó a 58\% a pesar de la polarización - y tal vez como consecuencia de ella-, aun cuando estaban en juego proyectos de país y de políticas públicas confrontadas —o quizá por esa misma razón-, lo cierto es que algo está pasando con la puesta en operación del modelo electoral, con la forma de hacer campañas, concentrada en lo mediático y, tal vez, con el desencanto de una democracia que no ha logrado convencer de sus bondades a la ciudadanía. Así se puede entender la brecha creciente entre el apoyo democrático, en teoría, y la escasa satisfacción con el funcionamiento de los gobiernos que surgen de procesos democráticos ${ }^{34}$.

Una investigación sobre el abstencionismo en las elecciones intermedias de 2003 arrojó algunos resultados interesantes que pueden servir para explicar lo ocurrido en 2006, sobre todo porque se trata de procesos de cultura política que tienen permanencia de largo plazo. En ese estudio, que se hizo con la aplicación de una encuesta, des-

${ }^{34}$ Según los datos de la encuesta Latinobarómetro de 2005, en México el apoyo a la democracia es de $59 \%$ y la satisfacción es de sólo $24 \%$; el promedio en América Latina es de $61 \%$ de insatisfacción y $31 \%$ de satisfacción.

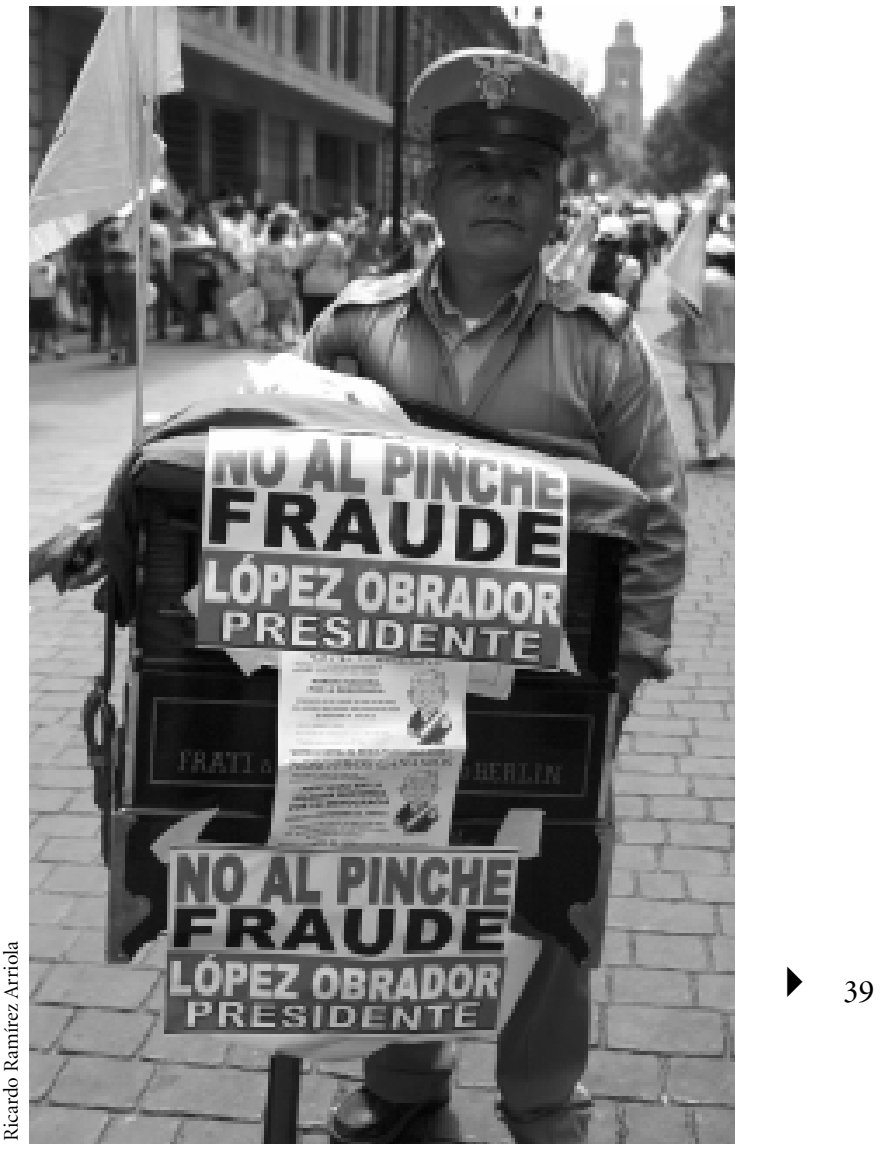

Segunda asamblea popular, Zócalo de la ciudad de México, 15 de julio de 2006.

tacan entre sus principales conclusiones las siguientes: la participación electoral aumenta en sectores que tienen, al menos, escolaridad de bachillerato, mayores de 24 años y con mayor información sobre la vida pública del país. Con esta base se plantea en el estudio que existen al menos dos tipos de participantes en los procesos electorales: los que están inmersos en "redes clientelares", que pueden ser los beneficiarios de algún programa de política social, y los ciudadanos que tienen mayor información política y más confianza institucional (Palma y Gutiérrez, 2004).

La otra cara de la moneda se refiere a que la falta de participación se explica por factores que pongo en sentido negativo, al contrario de las conclusiones del estudio citado, que los anota en sentido positivo: falta de un 
sentido de responsabilidad y de lealtad hacia el régimen democrático, falta de confianza institucional, ausencia de identificaciones partidistas fuertes, información insuficiente, campañas electorales poco atractivas y una acción poco eficaz en la promoción del voto (véase Lijphart, 2000).

El último punto de este apartado es el voto de los mexicanos en el extranjero, la única novedad en términos de reglas en este proceso. Se trató de un globo que se desinfló de forma paulatina. Las restricciones de la reforma sobre el tema cerraron las posibilidades de una participación masiva, pero aún así, el IFE solicitó una cantidad importante de recursos económicos en sus cálculos presupuestales para 2006: la suma fue de 1062 millones de pesos, equivalente a $8.2 \%$ del presupuesto general del IFE para $2006^{35}$. De un universo potencial estimado entre tres y cuatro millones de votos, la cantidad bajó sustancialmente al número de personas que solicitaron la información y las papeletas de votos, mediante un procedimiento complicado y costoso. Al final de cuentas se trató de una primera experiencia muy cercana a lo que puede calificarse como un fracaso ${ }^{36}$.

\section{CRISIS POSELECTORAL}

Ante un resultado controvertido — que dejó medio punto de diferencia entre Calderón y López Obrador-, después de una campaña de propaganda sucia, se generó una crisis poselectoral severa. Frente al conflicto se argumentó que existían canales institucionales y una vía legal para procesar el conflicto; sin embargo, en el horizonte inmediato del país se instaló un clima de incertidumbre y una severa confrontación que anunciaba una fase de mayor polarización a la que hubo durante la campaña electoral.

\footnotetext{
35 Datos del Acta del Consejo General del IFE, 18 de agosto de 2005, $<$ www. ife.org.mx $>$.

${ }^{36}$ Los números de la votación para presidente fueron irrelevantes en el conjunto: PAN, 19 016; Alianza por México, 1 360; Coalición Por el Bien de Todos, 11 088; Panal, 128; Alternativa, 887; no registrados, 29; votos válidos, 32 508; votos nulos, 623 ; total, 33 131. Cómputo distrital del voto de los residentes en el extranjero, en $<$ www.ife.org.mx $>$.
}

Para los que quisieron ver el problema de la noche del 2 de julio sólo como un tema de comunicación, había suficientes piezas para pensar que se trataba de un problema mayor que afectaba la confianza institucional y ponía en entredicho un proceso electoral con legitimidad democrática. El PREP fue el detonador que sembró la desconfianza porque 11184 casillas con inconsistencias no aparecieron en el total de votos computados ${ }^{37}$, error grave frente a una elección cerrada. A ello se sumó una larga lista de agravios y errores que se acumularon para formar un cuadro indeseable.

El conflicto poselectoral actualizó el fantasma del fraude y trajo a la memoria de millones de personas las elecciones de 1988. ¿Cómo era posible que de pronto hubiéramos llegado a este extremo?

El supuesto fraude, que aglutinó al movimiento de resistencia civil pacífica de la Coalición por el Bien de Todos, se basó principalmente en la siguiente argumentación: hubo errores aritméticos en 72197 casillas, 898862 votos sin sustento en boletas, 722326 votos eliminados artificialmente, con lo cual se forma un universo de 1621 188, pero en realidad la suma de los tres números anteriores es de 1693385 votos que supuestamente tienen afectación fraudulenta ${ }^{38}$. En realidad, el manejo sobre el fraude fue confuso; se argumentaba "fraude cibernético" y, al día siguiente, se decía que era un fraude a la antigüita. Un día se exhibían pruebas de rellenado de urnas en forma fraudulenta y al día siguiente salía la información real que desmentía el caso; llegaba la descalificación y el candidato de la Coalición señalaba que muchos de sus representantes habían sido comprados. Independientemente de que pudo haberse dado la compra de representantes, el caso mostrado a los medios no correspondía con el juicio descalificatorio.

En un estudio sobre los argumentos del fraude, que presenta la otra cara de la moneda, se hizo una sistematización de las irregularidades: comportamiento atípico

\footnotetext{
${ }^{37}$ Acuerdo del IFE, que no se comunicó de forma transparente ni en tiempo.

${ }^{38}$ Documento de la Coalición por el Bien de Todos, "Evidencias del fraude durante la elección y los cómputos que justifican la demanda de recuento".
} 
del PREP; votos nulos que eran para López Obrador; irregularidades en las actas de escrutinio; errores aritméticos en 72 mil actas; actuación incorrecta de los funcionarios de casilla; movilización del Panal a favor de Calderón; y sustitución no aleatoria de funcionarios de casilla por aliados de Calderón. Según este trabajo, la conclusión, después de hacer una revisión de cada tema, es que "los datos oficiales no muestran evidencia alguna de manipulación o fraude en la elección presidencial de 2006: no se encuentra en las inconsistencias del PREP, ni en los votos nulos de la elección presidencial, ni en las casillas con errores aritméticos, ni en los paquetes que se abrieron en el cómputo distrital"39.

El tema del fraude cohesionó el movimiento de resistencia y logró convencer a una parte importante de las bases de apoyo de la Coalición de que el fraude era una realidad palpable. Sin embargo, las pruebas que sustentaron la impugnación ante el TEPJF no pudieron sostener el argumento para revisar y recontar la globalidad de la elección. Como se verá más adelante, el TEPJF procedió a un recuento parcial y eso fue suficiente para que la consigna de "voto por voto y casilla por casilla" quedara desechada como posibilidad. Durante el tiempo que duró la crisis poselectoral tuve la certeza, o mejor dicho, la impresión, de que el problema importante no había estado tanto en la votación, sino en la campaña.

La polarización no surge sólo de los spots televisivos que se inician en marzo de 2006; ya había muchos antecedentes. Sin duda, la campaña fue un ingrediente del proceso electoral accidentado, de una alta confrontación y de una percepción sobre la falta de equidad en la contienda. A pesar de que los números y los montos gastados por los partidos no presentaban un diferencial importante, sí hubo la percepción, sobre todo por la intervención de terceros, desde el presidente de la República, grupos empresariales y otros actores que violentaron la legalidad abiertamente $y$, al parecer, de forma impune. La pasividad del árbitro en la regulación de la campaña negativa (artículo 38-p del Código Federal de Instituciones

39 "La evidencia del fraude", texto de Luis Estrada y Alejandro Poiré, quien fuera director ejecutivo de la dirección de partidos políticos y prerrogativas del IFE, agosto de 2006, en <www.ife.org.mx>. y Procedimientos Electorales, Cofipe), fue un factor que también afectó la contienda y que fue parcialmente corregido por el Tribunal, con efectos retardados en el proceso.

La intervención del ejecutivo, tanto vía los spots como en una permanente construcción de un discurso de ataque a uno de los contrincantes - como si el presidente fuera otro candidato más de la contienda-, dejó a Fox como uno de los principales responsables de la polarización. De la misma forma, también se lastimó la elección por no haber detenido la embestida de actores comprometidos con una opción política, como fue la intervención televisiva del Consejo Coordinador Empresarial y del autodenominado Dr. Simi que, en una abierta violación a la ley, emitieron decenas — quizá cientos— de spots en la fase final de la campaña ${ }^{40}$.

El marco legal señala en el artículo 48 del Cofipe:

1. Es derecho exclusivo de los partidos políticos contratar tiempos en radio y televisión para difundir mensajes orientados a la obtención del voto durante las campañas electorales $[\ldots]$ 13. En ningún caso se permitirá la contratación de propaganda en radio y televisión a favor o en contra de algún partido político o candidato por parte de terceros.

La misma noche de los comicios, el árbitro nuevamente no estuvo a la altura, no detuvo la avalancha de los candidatos y a ellos les importó poco el árbitro, porque esa noche violentaron la legalidad y los dos candidatos punteros se declararon vencedores. El 3 de julio fue el día en que el Programa de Resultados Electorales Preliminares (PREP) generó la duda por no decir claramente que las inconsistencias estaban en otro archivo al cual se llegaba a través de un laberinto informático de seis pasos. El 4 de julio el fantasma del fraude empezó a circular y se generalizó en la parte perdedora de la contienda. La diferencia entre los punteros - Calderón y López Obrador - se cerró progresivamente conforme se daba la información: en diferentes momentos del PREP tuvo un $1.04 \%$, pero terminó con sólo una distancia de $0.6 \%$. Entre el 5 y el 6 de julio, cuando se hizo el cómputo de las actas en los

\footnotetext{
${ }^{40}$ Es difícil saber con exactitud la cantidad porque estos actores no eran monitoreados por la autoridad electoral.
} 


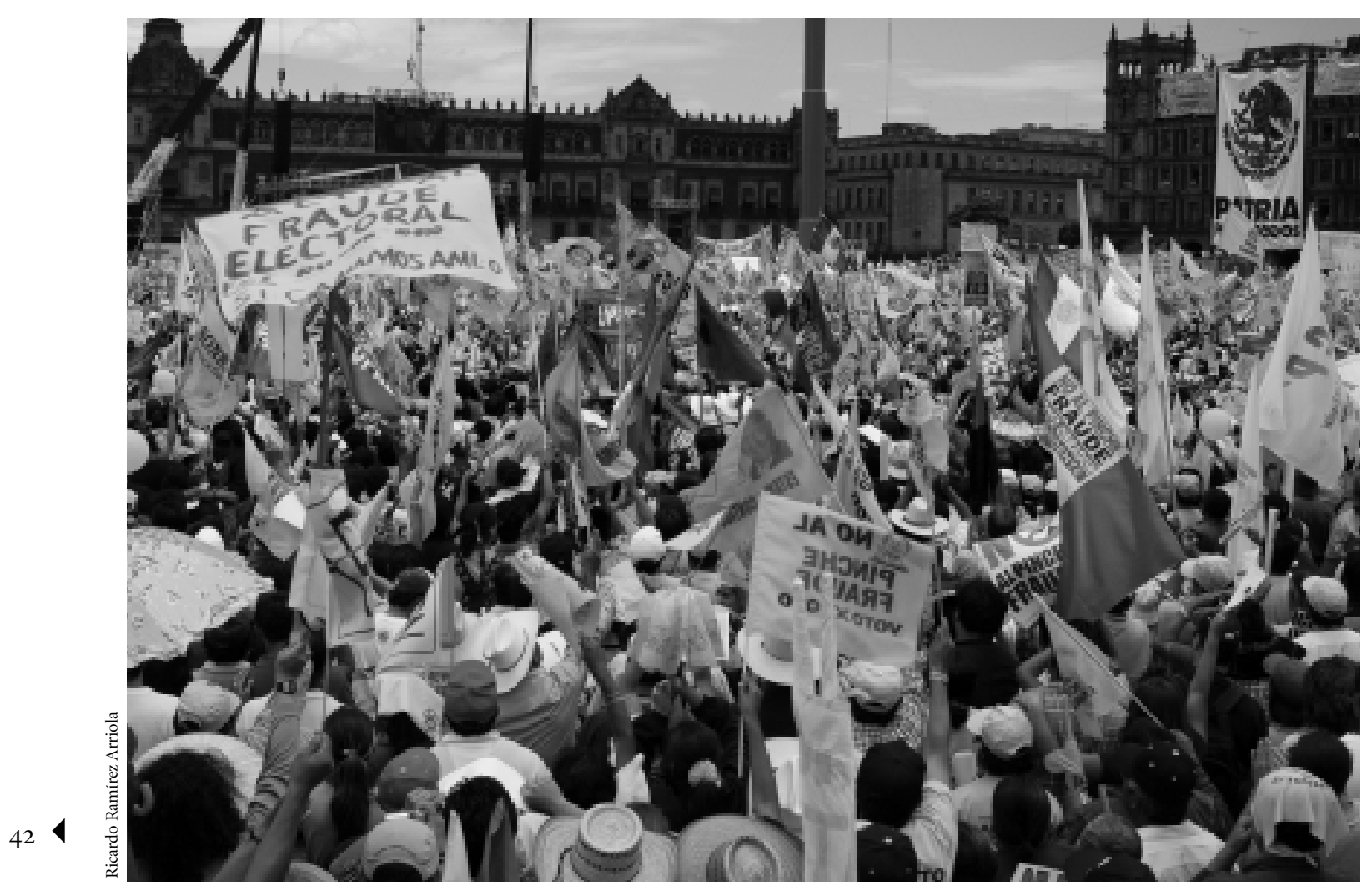

Segunda asamblea popular, Zócalo de la ciudad de México, 15 de julio de 2006.

300 distritos de todo el país, el resultado pasó a sólo una ventaja de $0.58 \%$ para Calderón, que sumó $35.89 \%$, contra $35.31 \%$ para López Obrador.

A partir de ese momento, la credibilidad del árbitro empezó a ser fuertemente cuestionada por una parte importante de la ciudadanía. Se había cometido un error estratégico en un momento crítico. Indebidamente también, el consejero presidente dio por ganador a Calderón, cuando la ley señala que sólo el secretario ejecutivo dará a conocer el resultado del cómputo distrital. La desconfianza institucional en el IFE se centraba en la incapacidad política de los consejeros, que no supieron reaccionar eficientemente frente a un escenario complicado.

El 6 de julio, López Obrador afirmó que no reconocía los resultados por haber muchas irregularidades y que impugnaría la elección en el Tribunal Electoral. Dos días después, en un Zócalo de la capital repleto de simpatizantes, el candidato de la Coalición por el Bien de Todos declaró enfático, frente a una multitud enojada, que en la elección se había cometido un "fraude" e hizo un llamado a una movilización nacional pacífica. Las elecciones de 2006 llegaban a un momento que había sido largamente construido: una crisis poselectoral que sacudiría a la incipiente democracia mexicana.

La tesis de hacer un recuento de voto por voto fue una demanda que se mantuvo durante todo la movilización, desde finales de julio hasta mediados de septiembre. Prácticamente durante 48 días se hizo un plantón del Zócalo de la capital, el corredor de las calles de Madero y Juárez, para continuar por Reforma hasta la fuente de Petróleos. El bloqueo de todas estas vialidades, que se hizo desde el 30 de julio hasta el 14 de septiembre, fue parte de un movimiento de resistencia que progresivamente elevó sus niveles de conflicto y radicalidad, pero que no tuvo ar- 
monía con la estrategia jurídica de impugnación. Simplemente se pedía el voto por voto, pero no se impugnó todo el conjunto. Por ejemplo, hubo 70 distritos que no tuvieron ninguna impugnación.

Antes de que se iniciara el plantón Zócalo-Reforma, López Obrador mandó a Calderón una carta en la que le pidió que aceptara el recuento global de la elección, pero la respuesta fue dejar todo en manos del Tribunal Electoral. Los argumentos de la carta de López Obrador y la respuesta de Calderón expresan de forma paradigmática el dilema y la apreciación sobre los comicios de 2006.

López Obrador le propone a Calderón que apoye el conteo de voto por voto y de casilla por casilla para no dejar ninguna duda y como el único mecanismo para reconocer un resultado. La visión de López Obrador es la que acusa que el proceso no fue limpio; textualmente afirma lo siguiente:

[...] como usted sabe, el proceso electoral estuvo plagado de irregularidades y de actos fraudulentos. Durante la campaña, el Consejo General del IFE actuó de manera facciosa; la publicidad en los medios de comunicación no fue equitativa; en su campaña se gastó dinero a raudales, de procedencia desconocida, y se rebasaron por mucho los topes establecidos por la ley; grupos de intereses creados pusieron en práctica un activismo ilegal; se recurrió a la "guerra sucia", a la mentira y a las campañas del miedo; se usaron los programas sociales del Gobierno federal y otros recursos públicos en apoyo a su candidatura; fue pública y notoria la injerencia del Presidente de la República para golpearnos. Y, por si todo esto no bastara, hubo manipulación en los sistemas de cómputo electoral y se falsificaron resultados en miles de actas de escrutinio.

Más adelante concluye la carta con lo siguiente: "En suma: si usted sostiene que ganó, si usted está convencido de que obtuvo la mayoría de votos, no tiene por qué negarse a despejar dudas y transparentar la elección. El que nada debe, nada teme" 41 .

La respuesta de Calderón a López Obrador fue negar el argumento central del fraude y, por supuesto, la negativa a aceptar el recuento, con el argumento de que él se sometería a la legalidad, a lo que decidiera el Tribunal, y que la decisión del recuento global no dependía de la opinión de los candidatos, sino de lo que marcaba la ley:

La contienda fue equitativa $[\ldots]$ los medios de comunicación estuvieron abiertos a todas las expresiones políticas [...] En suma, las elecciones federales para renovar el Poder Legislativo de la Unión y la Presidencia de la República fueron limpias, libres y democráticas [...] La decisión de recontar votos no corresponde a los candidatos ni a los partidos sino al Tribunal Electoral del Poder Judicial de la Federación [...] La petición que usted ha formulado no depende de lo que los candidatos opinemos sino de lo que la ley dispone. En mi caso respetaré escrupulosamente la resolución que el Tribunal determine respecto a su petición y, desde luego, acataré lo que resuelva respecto a las impugnaciones presentadas.

En la parte final de la carta se hace una invitación a dialogar al afirmar: "Este es el momento de la unidad nacional, de la concordia y de la paz" 42 .

Con este intercambio de cartas quedan manifiestas las posiciones del conflicto que se reproducirían dentro del clima de la crisis poselectoral que se vivió en el país entre julio y septiembre.

Durante años se ha discutido en la teoría política si lo importante para tener una democracia fuerte es una cultura política o si se necesitan más bien instituciones consolidadas. Las elecciones del 2 de julio actualizaron esta discusión, como vimos con la posición de los dos candidatos punteros en las cartas citadas. La división quedó entre los que hacían una defensa de las instituciones y señalaban que el proceso electoral y los comicios presidenciales se llevaron a cabo básicamente con respeto a la legalidad y dentro de los cauces institucionales (postura panista); y, por otra parte, el sector que no aceptaba los resultados porque consideraba que había sido una elección con muchas irregularidades e incluso con un "fraude" importante (postura perredista).

Mientras los que salieron arriba en el resultado defienden la institucionalidad, los que salieron abajo cuestionan a la institución porque, según ellos, la elección no fue limpia. De la misma forma en que una democracia sólo inicia

\footnotetext{
42 Reforma, 25 de julio de 2006.

${ }^{41}$ Reforma, 25 de julio de 2006. 
con un proceso electoral limpio y equitativo, pero no se agota en ese momento, una elección no es sólo lo que sucede en la jornada de votación, sino que tiene antecedentes que la marcan. En el tono de la campaña, en el perfil de cada candidato puntero y en las ofertas de país, podemos encontrar algunas claves que explican la polarización de un México contra otro México.

El candidato panista le dijo poco al sur del país, al México pobre, no hubo sensibilidad social; predominó un discurso sobre la competencia y el desarrollo, su oferta fue para el México del norte. Calderón, un panista del sector doctrinario, se arropó en un esquema de campaña muy golpeador. López Obrador, por su parte, estaba abajo en los resultados por los golpes sucios de sus antagonistas, pero también por un cúmulo de errores estratégicos y de comportamiento político. No se puede ganar la presidencia desde la exclusión de sectores importantes de la sociedad. Salirse del centro resultó crítico porque perdió el apoyo de miles de ciudadanos que no vieron en su discurso alguna referencia para sentirse representados. Al final de la campaña, ya demasiado tarde, cuando las apuestas estaban sobre la mesa, López Obrador empezó a decir que la economía tendría un manejo técnico y no ideológico. El candidato de los pobres les dijo muy poco a los ciudadanos de las clases medias.

Antes del 2 de julio era impensable adelantar el escenario de las calles del centro histórico de la ciudad de México tomadas por el PRD en protesta por un supuesto "fraude electoral". Un mes después del 2 de julio la nota dominante era el movimiento social que encabezaba López Obrador. Cuando la Coalición tomó la decisión de esperar en las calles de la capital la decisión del TEPJF, la crisis poselectoral se agudizó.

La ambigüedad del movimiento perredista fue moverse entre dos estrategias: la parte legal y los expedientes de la impugnación, por un lado, y la movilización social, por el otro. La afirmación de respetar la legalidad, pero al mismo tiempo establecer como requisito el conteo de voto por voto como única vía de tener certidumbre, fue la forma de condicionar la decisión legal al movimiento social. Pedirle a Calderón que no se declarara ganador o presidente electo, pero autoproclamarse como presidente ante las cámaras era un juego peligroso y contradictorio de
López Obrador. Afirmar en las asambleas informativas que existía la certeza absoluta del triunfo sin presentar pruebas era jugar a todo menos a la democracia.

El seguimiento de la información durante el primer mes después del 2 de julio mostraba diversas irregularidades, pero no propiamente un "fraude electoral", como afirmaban los integrantes de la Coalición con base en inferencias de datos parciales. Había una duda razonable sobre el resultado electoral, la cual se materializó en los expedientes de impugnación que se presentaron ante el Tribunal Electoral. La estrategia del movimiento perredista fue escalando niveles de radicalidad. Se pasó de la denuncia del "fraude" a la movilización permanente. Durante esas semanas la política regresó a los campamentos callejeros. La diferencia entre los movimientos del pasado reciente en contra del fraude y el actual eran las instituciones y la legalidad. Esa frontera fue, durante la crisis poselectoral, un delgado camino que al final se bifurcaría entre acatar la decisión o simplemente desconocerla.

Durante esos días muchos actores sociales tomaron partido y se pronunciaron públicamente sobre la división paradigmática entre el respeto a las instituciones o desafiarlas porque se habían comportado de manera facciosa. Así, la Iglesia pidió paz, pero al mismo tiempo se alineó con Calderón y el respeto institucional; de igual forma actuaron los empresarios; grupos de intelectuales $\mathrm{y}$ académicos se dividieron en sus posturas, que publicitaron en desplegados de prensa. Al correr de los días, el plantón de la Coalición empezó a generar malestar y afectó el respaldo a López Obrador; varias encuestas mostraron que el movimiento perdía apoyo por la radicalización y porque se afectó de forma importante la vialidad de la ciudad de México.

Lo que durante el proceso de desafuero en 2005 fue una de las piezas claves - el apoyo de la prensa extranjera a López Obrador-, ahora se convertía en un terreno sumamente crítico. Tanto en Estados Unidos como en Europa no se entendía cómo alguien podía jugar a la democracia, aceptar sus reglas y, al mismo tiempo, desafiar a las instituciones. Esa actitud y esa posición frente a las reglas del juego fueron los dos rasgos que marcaron la crisis poselectoral de 2006. 


\section{EL ÁRBITROY EL JUEZ DE LÍNEA: EL TRIBUNALY EL IFE}

Después de la reforma de 1996 se afirmaba en broma que, mientras el Tribunal era el árbitro, el IFE sólo era un juez de línea. De alguna forma, durante el proceso electoral de 2006 la broma se hizo realidad.

El cambio de consejeros en el año 2003 también representó una forma diferente de interacción entre el IFE y el TEPJF. El recurso de judicializar el proceso político fue un rasgo que se incrementó de forma importante en esos años, como un síntoma de la rudeza del juego entre los partidos. Una interpretación complementaria es que el grupo de consejeros (1996-2003) fue muy activo en su arbitraje, a tal grado que lo que no estaba en la ley se suplía con acuerdos e iniciativas. En cambio, el consejo que entra a finales de octubre de 2003 cambia radicalmente de actitud: se opera una suerte de sustitución de la imparcialidad por una supuesta actitud de neutralidad, que se tradujo en no tomar las decisiones necesarias y no hacer una operación política eficiente. Por ello, el TEPJF se volvió el organismo activo, "el gran remedio". El hecho de que los jueces se vuelvan tan activos no es una buena noticia. Se tenía que parar al anterior consejo; a éste, en cambio, había que moverlo para que actuara ${ }^{43}$. Si a esto se suma el problema de origen partidizado por las cuotas que se asignaron el PRI y el PAN para conformar el grupo de consejeros electorales, más las múltiples correcciones que hizo el TEPJF a decisiones del IFE, se tienen las pinceladas de un árbitro que resultó faccioso e ineficiente resultado de un temprano acuerdo entre Elba Esther Gordillo y Felipe Calderón - para organizar un proceso electoral tan complicado como el de 2006.

Las instituciones electorales han pasado por varias pruebas electorales que han superado a lo largo de los últimos diez años: las intermedias de 1997 y 2003, y las presidenciales del año 2000. Sin embargo, durante el proceso electoral de 2006, el IFE - y sobre todo sus conse-

${ }^{43}$ Esta interpretación fue parte de las opiniones del consejero y especialista electoral, Alfredo Orellana, en el "Foro sobre la reforma electoral. Lecciones aprendidas", organizado por el Comité Conciudadano de Seguimiento al Proceso Electoral, 17 de octubre de 2006. jeros electorales - perdió credibilidad y confianza para una parte importante de la sociedad, por su origen y su desempeño ineficiente. La metáfora de Clara Jusidman, integrante del Comité Conciudadano de Seguimiento al Proceso Electoral, ilustra bien lo que ha sucedido con el IFE a partir de la renovación de 2003: "El IFE es como un portaviones guiado ahora por una tripulación de barco pesquero de ribera... con sus notables excepciones" 44 .

Una tripulación de ribera no tiene experiencia para navegar en alta mar, quizá por ello las críticas al desempeño de los consejeros electorales se multiplicaron cuando hubo oportunidad de hacer los balances. Sobre el proceso de organización interna hubo críticas que circularon en la opinión pública; por ejemplo, la falta de una plena conciencia sobre la importancia de los comicios de 2006; que se dedicó demasiado tiempo a las precampañas y a estar en "los reflectores" con el afán de obtener una legitimidad que les fue cancelada por los mismos partidos al momento de elegirlos sin consenso; el descuido de la estructura y la falta de un seguimiento puntual del proceso electoral. Las críticas de los mismos consejeros locales sobre el proceso de capacitación es un indicador relevante, como se verá enseguida. Al parecer hubo una falta de jerarquía; se dedicó mucho tiempo a temas poco importantes como las campañas de difusión, y no se priorizaron de forma correcta las partes sustantivas del proceso.

Dejemos de lado las críticas externas y vayamos a las internas, las que se hacen con más conocimiento de causa. En un foro de análisis sobre el proceso electoral, un grupo importante de consejeros locales hizo un balance sumamente crítico sobre el desempeño de los consejeros electorales: tibieza frente al acuerdo de neutralidad que prohibía a las autoridades de los diversos niveles de gobierno involucrarse en el proceso electoral a partir del 23 de mayo, es decir, 40 días antes de las elecciones; falta de autoridad frente a intervenciones ilegales de la Iglesia católica y de los empresarios a favor del PAN; falta de profesionalismo en la toma de decisiones; desarticulación entre la Junta General Ejecutiva y el Consejo General; deficiencias en el servicio profesional electoral; confronta-

\footnotetext{
${ }^{44}$ Entrevista en la revista Proceso, núm. 1549.
} 
ción en las juntas locales y falta de liderazgo del Consejo General; falta de respuesta de los consejeros; diez veces más alto el número de sustituciones para la integración de los funcionarios de casilla, lo que indica un fracaso de las políticas de capacitación y organización electoral. Una de las conclusiones que se puso sobre la mesa es que si el Consejo General del IFE no trabaja de forma eficiente, las otras partes del IFE tampoco lo harán, sobre todo porque el peso de esta instancia directiva es sumamente fuerte en el resto de la estructura institucional. Otra conclusión importante fue la necesidad de revisar el modelo del IFE como estructura ciudadanizada ${ }^{45}$.

Otro indicador sobre el nivel de crítica que tenía el grupo de consejeros electorales fue un sondeo que hizo el suplemento Enfoque del diario Reforma con un grupo de editorialistas: de un total de 27 personalidades políticas que complicaron el proceso electoral, los consejeros del IFE aparecen entre los más citados. En primer lugar estaba Fox (85\%), luego Elba Esther Gordillo (67\%), Marta Sahagún y Roberto Madrazo (64\%), Manuel y Jorge Bribiesca, y René Bejarano (61\%), Arturo Montiel y Ulises Ruiz (58\%), y los consejeros del IFE (55\%). Entre las menciones del grupo de editorialistas aparecen opiniones como las siguientes: "Porque no estuvieron atentos al cumplimiento de sus funciones. Fueron omisos en imponer respeto entre los partidos, salvo cuando el Tribunal Electoral les llamó la atención"; "por presuntos enlaces irregulares con panistas y retrasos en el manejo de las denuncias"; "tuvieron resoluciones contrarias a la libertad de expresión y al libre desahogo de la crítica"; "la suma de su inexperiencia con las críticas al momento de su nacimiento crearon un ambiente poco propicio para que fueran exitosos"; "se mostraron muy débiles al no detener las campañas sucias" 46 .

Uno de los grandes aciertos de la reforma electoral de 1996 fue el diseño institucional de contar con un Tribunal de pleno derecho dentro de la estructura del poder

${ }^{45}$ Reunión celebrada en Cuernavaca, Morelos, el 29 de julio de 2006, en la cual participaron consejeros locales de Oaxaca, Distrito Federal, Puebla, Chihuahua, Nuevo León, Morelos, Estado de México, Chiapas y Querétaro.

46 Enfoque, núm. 642, suplemento de Reforma, 9 de julio de 2006. judicial. Con este Tribunal, el país cambió de un paradigma contencioso político que funcionó desde 1824 a otro de carácter contencioso judicial. En lugar de que el propio poder legislativo califique las elecciones (era juez y parte), como lo hizo en el pasado, el nuevo diseño consistió en tener un organismo autónomo, tanto en materia jurisdiccional como administrativa.

En los primeros diez años de este Tribunal se desarrolló un complejo mecanismo de medios de impugnación que cubre dos sistemas contenciosos: uno de tipo administrativo, que tiene que ver con los recursos de revisión del IFE, y otro de tipo jurisdiccional, que dictamina las impugnaciones electorales. Uno de los magistrados del Tribunal expone en números y porcentajes cómo se ha comportado el Tribunal frente a los recursos presentados por los partidos, con lo cual se establece un criterio de confiabilidad: entre 1996 y 2005, el PAN presentó 802 medios de impugnación y se le ha dado la razón en 166 (21\% de los casos); el PRI presentó 831 y ganó 169 (20\%), y el PRD presentó 856 y ganó 193 (23\%) (véase Orozco, 2005). Este Tribunal ha emitido sentencias que han sido muy discutibles y que muchas veces han dejado inconformes a los actores políticos. Ha habido casos conflictivos y muy polémicos, como las anulaciones en las gubernaturas de Tabasco y Colima, o en municipios como el de Ciudad Juárez, en los que hubo una intervención facciosa de la autoridad gubernamental que desequilibró el resultado electoral. También han sido criticadas las decisiones contrarias de no anular, como en los cerrados comicios de Veracruz y Oaxaca en 2004.

Otro tema importante ha sido el de la protección de los derechos políticos y la democracia interna de los partidos, como sucedió con el Partido Verde, al que obligó a hacer de nuevo sus estatutos porque tenían un perfil completamente autoritario. Uno de los problemas frecuentes que ha dictaminado el Tribunal es el de las multas y sanciones por motivos de financiamiento ilegal de los partidos, como sucedió con los expedientes de Amigos de Fox y Pemexgate.

El activismo del TEPJF y la falta de eficacia del IFE se expresaron en los 46 juicios de apelación promovidos desde diciembre de 2003 por el Tribunal. Prácticamente 1.2 veces por mes en promedio se revocaron decisiones to- 
madas por el consejo general del IFE; también, "en 19 juicios para la protección de los derechos político-electorales del ciudadano, los fallos del Consejo debieron modificarse" 47 .

Uno de los momentos importantes de las múltiples modificaciones que ordenó el TEPJF al IFE fue sobre la propaganda sucia. El 5 de abril de 2006 el Tribunal determinó que sí procedía la queja de la Coalición por el Bien de Todos y ordenó al PAN retirar tres de los cuatro spots en donde se atacaba a López Obrador; y al PRI se le ordenó suprimir la frase "mentir es un hábito para ti", atribuida a López Obrador.

El fondo de la discusión, la litis central, consistió en determinar si el contenido violaba o no el régimen jurídico aplicable a la propaganda en el curso de la campaña electoral. Se trató de analizar y dictaminar si las campañas debían tener una libertad de expresión absoluta o, por el contrario, si los partidos son entidades de interés público que operan con financiamiento público y se tienen que someter a las reglas que marca el Cofipe en su artículo 38, párrafo 1, inciso p, en el cual se obliga a los partidos políticos a abstenerse de hacer propaganda que contenga diatriba, calumnia, infamia, injuria, difamación y denigración. La conclusión de la mayoría de los magistrados fue que en los spots en disputa se infringía la ley con frases vejatorias, deshonrosas y que llegaban al oprobio $^{48}$. La decisión del Tribunal en esta materia fue por mayoría y no por unanimidad, porque hubo un voto particular de uno de los magistrados, quien defendió el principio de la libertad de expresión; la mayoría votó por detener algunos mensajes que estaban dentro de lo señalado por el Cofipe ${ }^{49}$. El caso fue tan importante que la resolución del TEPJF señaló que era "la primera vez que la Sala

\footnotetext{
${ }^{47}$ Enfoque, núm. 656, suplemento de Reforma, 15 de octubre de 2006. ${ }^{48}$ Según el informe sobre los procedimientos especializados en materia de spots de las campañas electorales durante el proceso electoral 20052006 del IFE, la Coalición por el Bien de Todos presentó 14 recursos, aunque al sumar salen 15; se le concedió la razón en once, de los cuales en cuatro el TEPJF modificó la resolución del Consejo General del IFE. El PAN presentó nueve escritos y en siete ocasiones el IFE consideró que estaban fundados; la Alianza por México presentó cinco recursos y sólo dos fueron considerados como fundados.

49 TEPJF, expediente: SUP-RAP-34/2006 y Acumulado, <www.trife.gob. $\mathrm{mx}>$.
}

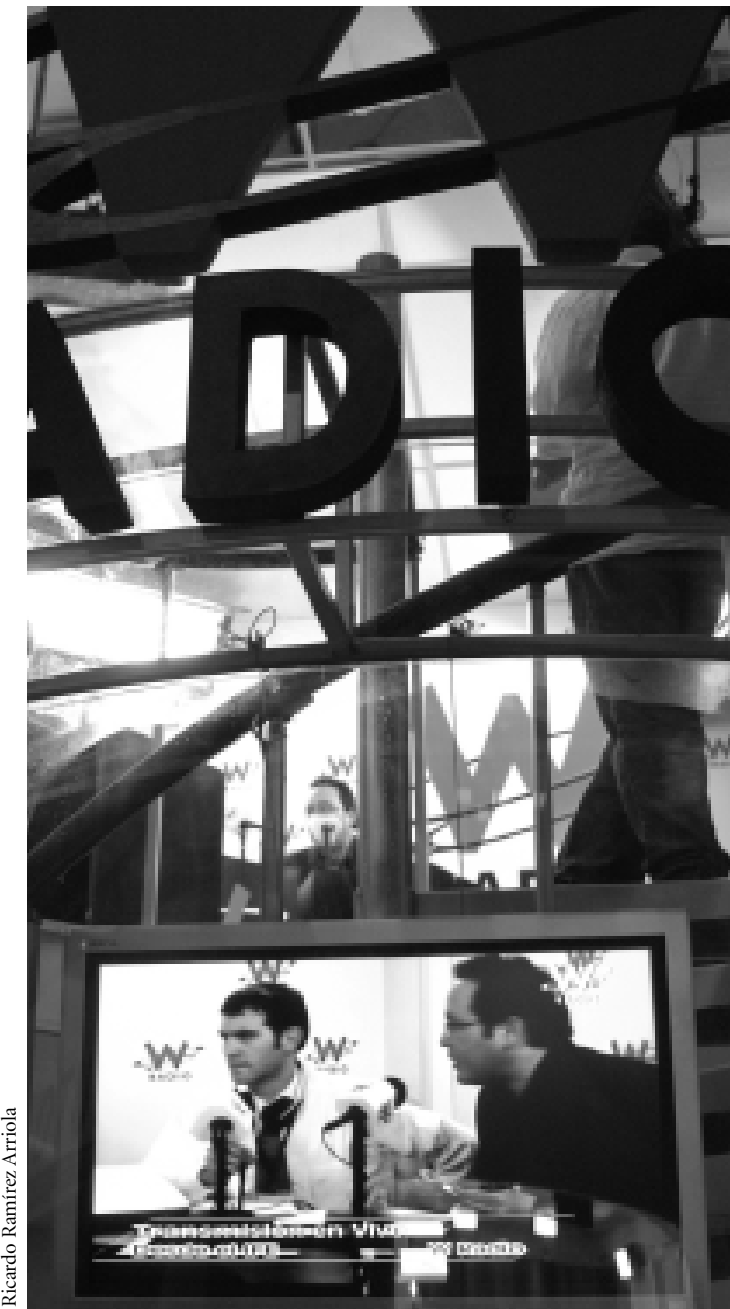

Medios de comunicación en la sede del IFE, 2 de julio de 2006.

Superior realiza un pronunciamiento de fondo en materia de libertad de expresión" 50 .

De forma directa, la crisis poselectoral afectó a las instituciones que posibilitaron la construcción de la democracia en México. El IFE y el TEPJF fueron el corazón de las reglas de la reforma de 1996. Su aporte básico fue la autonomía, que posibilitó construir durante años la confianza de que los votos serían contados de forma limpia,

\footnotetext{
50 TEPJF, expediente: SUP-RAP-31/2006, <www.trife.gob.mx>.
} 
que los competidores tendrían condiciones equitativas para disputarse el poder y que las controversias tendrían una ruta institucional de solución. Con esa garantía se dejaría atrás la protesta callejera que caracterizó a las elecciones impugnadas durante la década de 1980 y la mitad de la de 1990. El conflicto de 2006 mostró un debilitamiento de esa confianza, sobre todo en el IFE, porque el TEPJF funcionó, como vimos antes, como un correctivo permanente a lo largo del proceso electoral. Los cuestionamientos sobre la solvencia del Tribunal se iniciaron con las primeras decisiones para resolver las impugnaciones de la elección presidencial y la sentencia que emitió el 5 de septiembre.

El centro del debate político con la crisis poselectoral fue en torno a la disyuntiva de contar otra vez los votos - la famosa consigna de "voto por voto"- o simplemente atender las impugnaciones que habían hecho los partidos ante el TEPJF. La primera decisión del Tribunal, el 5 de agosto, fue hacer un recuento de sólo 11839 casillas ubicadas en 149 distritos de 25 estados del país, con lo que se desechó la petición —más política que jurídi$\mathrm{ca}-$ de hacer un recuento general.

El procedimiento fue el siguiente: el TEPJF recibió 335 juicios, 231 de la Coalición por el Bien de Todos, 133 por parte del PAN y un juicio ciudadano. Del total de los juicios, el Tribunal separó los que eran de recuento de los de nulidad; de esta forma, la Coalición presentó 174 para recuento de votos y 57 para anular casillas; los del PAN eran todos de nulidad de casillas; los 174 juicios presentados por la Coalición cubrían un total de 21786 casillas, el Tribunal desechó juicios en 25 distritos, que cubrían a 9947 casillas, y aceptó juicios en 149 distritos que abarcaban 11839 casillas. Con este recuento parcial se haría el cómputo y, una vez terminados los juicios, el Tribunal ordenaría la corrección distrital sumando casillas no impugnadas y restando las casillas anuladas. Una vez terminada la sumatoria, se procedió a hacer un análisis de las condiciones de la elección y del juicio de "nulidad abstracta" para, en su caso, determinar la validez del proceso y declarar presidente electo ${ }^{51}$.

${ }^{51}$ Información que se desprende de un esquema elaborado por Análisis y Diseño (ADN).
Dadas las dudas razonables que había en torno al cerrado resultado electoral y frente al movimiento de resistencia que estaba en las calles de la ciudad de México, se generó una corriente de opinión favorable hacia el conteo general y la revisión íntegra de la elección, sobre todo para resolver la incertidumbre y las dudas que ésta despertó. Sin embargo, el Tribunal tomó su decisión basado en el siguiente razonamiento: "la Coalición por el Bien de Todos no impugnó todos los distritos electorales ni cuestionó la totalidad de las casillas instaladas para la elección de Presidente de la República”. También, porque "los hechos que invocó con el propósito de extraer una causa genérica para la realización de ese recuento, invocando el principio de certeza que rige todo el proceso electoral, no están vinculados con la etapa del conteo de votos en las mesas directivas de casilla o en los cómputos llevados a cabo por los consejos distritales" 52 .

Con esta resolución, el TEPJF estableció las razones por las que no hizo un recuento completo; el segundo punto del argumento fue que los hechos presentados por la Coalición correspondían a otras etapas del proceso y no al momento electoral.

La lógica jurídica implica un razonamiento procesal que no está sujeto a la lógica política de los actores que impugnan una elección. La reacción política de la Coalición fue de rechazo al recuento parcial. Los litigios jurídicos nunca satisfacen a las dos partes porque afectan los intereses de una de ellas. El resultado de ese conteo, por su distribución regional y distrital, llevó a una corrección y su correspondiente rectificación de los resultados, pero fue para todos los candidatos en condiciones relativamente proporcionales, lo cual descartó la sospecha de que existía una manipulación que sólo beneficiaba a una de las partes y perjudicaba a la otra.

Mientras la vía jurídica seguía su ruta, la clase política mostraba sus miserias en actitudes irresponsables, ya que continuaba arrojando gasolina a la polarización: López Obrador afirmaba que los magistrados del TEPJF podían recibir "cañonazos", y más tarde declaraba al diario Le Monde que en México habría dos presidentes. Por su

\footnotetext{
52 TEPJF, Boletín de prensa, núm. 074 / 2006, <www.trife.gob.mx>
} 
parte, el presidente Fox afirmaba ante corresponsales extranjeros que Calderón era un "claro ganador" y que el Tribunal lo declararía presidente electo; al mismo tiempo, también repetía que el problema poselectoral se reducía a una calle de la ciudad de México. Una vez más, el presidente armaba su agenda discursiva para responderle a López Obrador, así como lo había hecho durante la campaña electoral. En esos días, Calderón hacía giras de "agradecimiento" y llamaba al "diálogo" a la otra parte. Estas reacciones de los actores daban cuenta de que los cauces políticos de la incipiente democracia mexicana estaban severamente lastimados.

La sala superior del Tribunal resolvió que no había fraude generalizado y como resultado del cómputo de las 11839 casillas, hizo ajustes que no cambiaron los resultados de forma relevante, ni tampoco al ganador. Se anularon 81061 votos por Calderón y 75355 por López Obrador ${ }^{53}$. Incluso, uno de los magistrados señaló que la Coalición había entregado, en la mayoría de las demandas, "machotes", lo cual implica una debilidad en las pruebas. Sin embargo, el Tribunal nunca transparentó por qué unas urnas sí se abrieron y otras no. Una duda no resuelta es que los magistrados hubieran podido ordenar la apertura de todos los paquetes y recontar toda la elección, lo que hubiera sido completamente legal. Nunca se despejó esta incertidumbre porque no se sabe si en algún momento del recuento se hubiera cambiado al puntero de la elección. Con una decisión de este tipo, el cómputo final que hizo el TEPJF dejó una diferencia de sólo 233831 votos entre Calderón y López Obrador, como se puede ver en el cuadro 7 .

Después de estas resoluciones, el espacio para las conjeturas disminuyó de forma sensible, porque ya sólo quedaban abiertas dos conclusiones: una muy probable —ratificar el triunfo de Calderón y declarar la validez de la elección — y la otra, muy remota — declarar sin validez la elección y recurrir a la "causa genérica de nulidad"

${ }^{53}$ La Coalición por el Bien de Todos contradijo al TEPJF y señaló que había irregularidades en $65 \%$ de las casillas del recuento, correspondientes a 3873 casillas, porque supuestamente había votos "espurios"; además, en otras 3659 casillas se habían extraído votos. La Jornada, 25 de agosto de 2006.
Cuadro 7. Cómputo final de la elección para presidente de la República, 2006

\begin{tabular}{lr}
\hline PAN & 14916927 \\
\hline APM & 9237000 \\
\hline CPBT & 14683096 \\
\hline PNA & 397550 \\
\hline PASC & 1124280 \\
\hline No registrados & 298204 \\
\hline Válidos & 40657057 \\
\hline Nulos & 900373 \\
\hline Total & 41557430 \\
\hline
\end{tabular}

FUENTE: TEPJF, Boletín de prensa, núm. 081/2006, <www.trife.gob.mx>.

por los 21 argumentos de inequidad y de ilegalidad que había presentado la Coalición- Al mismo tiempo, se alejaba la posibilidad de una salida institucional que dejara legitimado un triunfo para las dos partes.

El problema de la sospecha sobre la limpieza de la elección se presentaba como un paradigma de oposiciones del siguiente tipo: fraude o simples irregularidades; vía institucional o movimiento de resistencia; conteo general o parcial; respaldo a las instituciones electorales o crítica a ellas. En el fondo estaba en juego la sustentabilidad misma de la incipiente democracia mexicana.

Cuando se habla de instituciones no sólo se trata de las reglas del juego; también es muy importante el desempeño de los encargados de la institución y el tipo de vinculación que mantienen con la sociedad y con los principales involucrados en el espacio especializado que manejan. Las instituciones electorales no se vulneran con la crítica, sino por la acción directa de los actores. El IFE fue vulnerado por los mismos partidos cuando se renovó a los consejeros electorales en 2003; desde ese momento perdió la confianza de una de las fuerzas políticas. También por no aplicar la ley durante la campaña sucia, por la falta de una posición enérgica para detener la propaganda sucia — como le ordenó el mismo TEPJFy por no detener a los otros actores que participaron de forma ilegal en la contienda, como ya hemos señalado anteriormente. 


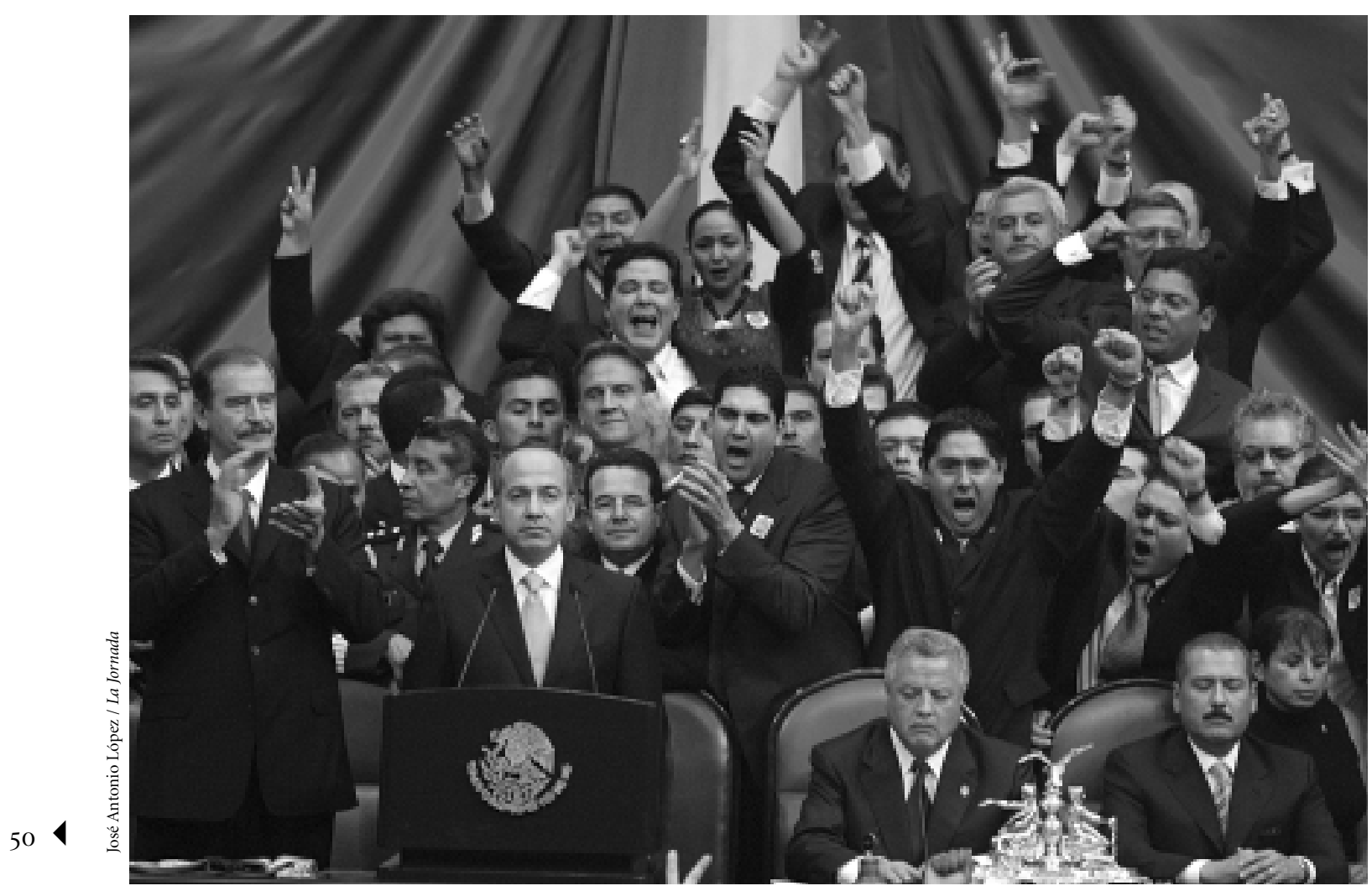

Toma de protesta de Felipe Calderón como presidente de México en el recinto legislativo de San Lázaro, $1^{\circ}$ de diciembre de 2006.

\section{EL POLÉMICO DICTAMEN DEL TRIBUNAL}

El proceso electoral terminó con el dictamen del Tribunal Electoral del Poder Judicial de la Federación, pero las secuelas del conflicto no concluyeron. El dictamen hizo posible asomarse a las entrañas de una elección y conocer las cañerías del sistema político y las herramientas jurídicas para resolver los litigios electorales.

La decisión del Tribunal fue desconcertante. Marcó el fin de un largo y agotador proceso electoral, pero no resolvió la incertidumbre sobre el litigio electoral. La palabra del Tribunal es la última en la materia, y su discurso tiene un carácter preformativo: lo que dice se hace y se cumple. Un mes después de haber ordenado el conteo parcial de los votos y después de haber resuelto los 335 juicios de impugnación, el TEPJF validó la elección y declaró presidente electo a Felipe Calderón el 5 de septiem- bre de 2006. El dictamen redefinió también la correlación de las fuerzas entre los actores: a los "perdedores" se le terminó la pista institucional del proceso y la ambigüedad de jugar en dos canchas - la de las instituciones y la del movimiento social—; para la parte "ganadora" el reto era mayúsculo, empezando por el déficit de legitimidad, porque para muchos ciudadanos no había sido un triunfo limpio, por lo que vino el conflicto que terminó en ruptura.

Las 309 páginas del dictamen dejan ver cómo funcionan los recursos jurídicos en materia electoral, sus posibilidades y sus enormes limitaciones. El dictamen mostró un débil razonamiento jurídico y un análisis parcial y sesgado de las pruebas. La parte impugnadora decidió no aceptar el fallo jurisdiccional y las críticas fueron múltiples. El Tribunal se metió en un camino complicado que le impidió un razonamiento limpio y una coherencia ló- 
gica en el análisis. Reconoció los problemas, las ilegalidades, las violaciones, las intromisiones y la participación indebida, pero a la hora de la ponderación y el balance, relativizó cada una de las pruebas con el argumento de que no había una forma de medir el efecto de esas acciones en el voto. Para los magistrados no era posible saber cómo se había afectado el proceso por la intervención ilegal de los actores porque supuestamente no se tenía el instrumento para ello, pero al mismo tiempo sí se podía saber que la afectación había sido menor. El siguiente párrafo del dictamen ejemplifica de forma nítida el problema anterior:

[...] esta Sala Superior no pasa por alto que las declaraciones analizadas del presidente de la República Vicente Fox Quesada se constituyeron en un riesgo para la validez de los comicios que se califican en esta determinación que, de no haberse debilitado su posible influencia con los diversos actos y circunstancias concurrentes examinados detenidamente, podrían haber representado un elemento mayor para considerarlas determinantes en el resultado final ${ }^{54}$.

Los magistrados analizaron cada una de las intervenciones indebidas e ilegales, pero en unos casos determinaron que su importancia era menor, en otros simplemente asumieron que no se daba el mecanismo de causa-efecto entre la falta y una consecuencia, y en unos más asumieron que no era posible medir los efectos. Por ejemplo, ¿cómo se puede saber que se debilitó el efecto de la intervención foxista si no se tiene un instrumento para medir sus efectos en el voto? El problema no consistió en la carencia de un instrumento para medir los efectos de las violaciones, sino en el hecho de no establecer ningún parámetro para saber cuándo la violación a una disposición jurídica — desde el Cofipe hasta la Constitución — tiene consecuencias - o no- para una elección:

¿Cuánto tiempo más de declaraciones del presidente Fox hubieran sido determinantes (ya que el dictamen dice que

\footnotetext{
${ }^{54}$ Expediente del TEPJF, "Dictamen relativo al cómputo final de la elección de Presidente de los Estados Unidos Mexicanos, declaración de validez de la elección y de presidente electo", 5 de noviembre de 2006, pp. 202-203, <www.trife.gob.mx>.
}

el Presidente se detuvo a tiempo)? ¿Qué intervenciones adicionales del CCE hubiesen sido necesarias para transformarlas en determinantes? ¿Cuánto más cerrada debió haber sido la elección para que cada acto fuera determinante?55

En algún momento del dictamen se hubiera esperado una valoración global de las impugnaciones, pero como se hizo el ejercicio de analizar de forma separada cada argumento, en ningún momento se volvieron a juntar las piezas, salvo para una enumeración final, pero no para interpretar un clima social y político de alta densidad. Prácticamente cualquier ciudadano que haya estado en México durante el proceso electoral pudo experimentar el bombardeo televisivo de los partidos y la ilegal intervención de los terceros. De nueva cuenta quedó la sensación de impunidad, de que se puede hacer prácticamente cualquier violación en materia electoral y no pasa nada. Además, la Fiscalía Especializada para la Atención de Delitos Electorales (FEPADE) fue prácticamente un fantasma durante todo el proceso electoral.

Entre las críticas que se hicieron al dictamen se puede destacar la siguiente:

La aprobación del dictamen no fue producto de una deliberación pública entre argumentos y razones. El órgano colegiado pierde sentido y no le da a la sociedad la posibilidad de conocer las distintas posturas y matices entre los magistrados. Hay, por tanto, un déficit con la transparencia. Es un tribunal opaco (Cárdenas, 2006).

Es necesario establecer que en todas las fases del proceso de resolución de controversias y de calificación del proceso electoral de 2006, los magistrados votaron de forma unánime. La disciplina interna prevaleció, no hubo votos particulares ni votos en contra de las resoluciones y del dictamen final.

Otra crítica fue la que hizo el Comité Conciudadano de Seguimiento del Proceso Electoral, del que retomamos varias preguntas que ejemplifican la falta de certidumbre que dejó el dictamen:

\footnotetext{
$559^{\circ}$ Comunicado del Comité Conciudadano de Seguimiento al Pro-
} ceso Electoral, 12 de noviembre de 2006. 
- ¿Por qué redactar el dictamen como sentencia y no como una resolución, si al final se argumentaría la falta de una vía legal para atender las peticiones de los partidos políticos?

- ¿Por qué responder y dar por resueltos todos y cada uno de los argumentos de los partidos políticos, para declararlos improcedentes de forma absoluta, si no se reconocería su derecho a promover acciones en la etapa de calificación de la elección?

- Si el Tribunal iba a resolver la improcedencia ante la falta de elementos adicionales, ¿por qué no ordenó diligencia o acciones para allegarse de más información?

- ¿Por qué se califica de ilícita la conducta de terceros sin que se les haya llamado a rendir cuentas?

- ¿Por qué el TEPJF estudió y valoró los diferentes argumentos que le fueron presentados por las partes uno por uno, de manera independiente o aislada, como si se tratara de una sentencia en un juicio?

- ¿No hubiera sido preferible y más adecuado una valoración articulada e integral, que sopesara los argumentos que cuestionaban (o sostenían) la validez de la elec- ción desde una perspectiva sistémica y no como meros hechos aislados?

- En suma, ¿por qué el dictamen parece resolver un juicio que nunca fue desahogado?56

Es posible que los empresarios del Consejo Coordinador Empresarial hayan esbozado una sonrisa amplia al ver que sus spots televisivos violaron la legalidad, pero su efecto fue nada más "tantito"; los panistas y los priístas, que inundaron de propaganda sucia la campaña electoral violentando el artículo 38 del Cofipe, debieron ponerse de fiesta porque no se sabe si su estrategia, según los magistrados, causó efectos en el voto, cuando todas las encuestas mostraron el cambio en las intenciones del voto con la mercadotecnia sucia. Quizá uno de los actores que debió sentirse desconcertado con el dictamen del TEPJF fue el denominado Dr. Simi, porque violentó todas las reglas, pero según el Tribunal, esto no afectó la contienda: tanto dinero gastado en horario estelar para nada,

$569^{\circ}$ Comunicado, op. cit. pero, tal vez, al final de cuentas se podrá consolar porque no tuvo ninguna sanción, promocionó su persona, jugó al independiente y anunció su marca de farmacias por todo el país, así que salió negocio redondo.

Con este dictamen, el Tribunal Electoral hizo prácticamente inviable la posibilidad de anular en el futuro cualquier proceso electoral con el sistema de medios de impugnación. Incluso, con el razonamiento que se emplea en este dictamen no se hubieran podido anular elecciones como la de Tabasco y Colima, porque cualquier prueba se hubiera podido relativizar. La famosa causal abstracta de nulidad, que circuló como fantasma en el imaginario del país durante varias semanas, quedó prácticamente desechada. Un signo de este problema es que en las entrevistas que realizó el Senado para elegir a los nuevos magistrados del TEPJF, una preocupación general de los candidatos fue la necesidad de reformar la ley de medios de impugnación para que esta figura pudiera tener una mayor especificidad.

Si se pensaba que el principal enfoque de una futura reforma tenía que ver sólo con las reglas electorales y con el IFE, ahora sabemos que también es necesario reformar el sistema de medios de impugnación porque tiene limitaciones tan fuertes que permite hacer dictámenes como el del 5 de septiembre. Las debilidades del dictamen son evidentes con una simple lectura: se juega con los términos de referencia y se aplican dosis amplias de subjetividad; además, se le quita fuerza a las pruebas para reforzar conclusiones. En la lógica argumentativa del dictamen se junta y se separa según convenga, para llegar a la conclusión prefijada desde el principio.

El fin de las elecciones abrió otra etapa. Es posible que con la polarización existente en esos momentos en el país ningún dictamen hubiera sido satisfactorio, pero el que se emitió generó dudas fundadas sobre su coherencia interna y sobre su capacidad para generar certidumbre, que era una de las demandas centrales al Tribunal.

\section{¿CUÁL FUTURO?}

El proceso electoral de 2006 mostró que el mundo de las instituciones democráticas es todavía demasiado precario. 
Una parte importante de los avances de la reforma de 1996, y de las garantías de tener elecciones equitativas y transparentes, quedó en entredicho. El ciclo virtuoso de las instituciones democráticas - IFE y TEPJF- se agotó y el proceso de 2006 fue la evidencia de que con esas reglas y con el desempeño faccioso y excluyente de los principales actores en este proceso era prácticamente imposible que no regresara un escenario conflictivo, como sucedió.

Los datos muestran que continuar con ese modelo de financiamiento hará de los procesos electorales un barril sin fondo; de la misma forma, mantener el esquema de acceso a medios masivos llevará a un gran gasto inútil y, al mismo tiempo, a mantener un empobrecimiento del debate político, además de ser un modelo que fácilmente lleva a campañas sucias y a la polarización de la sociedad.

A lo largo de este trabajo hemos examinado cómo las reglas sobre el financiamiento y el esquema de acceso a medios masivos generaron un modelo con incentivos perversos para un desarrollo político democrático. El golpe a la ciudadanización del IFE en 2003, agravado por el desempeño deficiente de los consejeros electorales en los momentos críticos de esta elección, fue la confirmación de que se había lastimado la confianza de una parte de la sociedad. Al mismo tiempo, los conflictos de este proceso volvieron a hacer patente lo que ya era una realidad confirmada desde procesos anteriores: mientras no se cambien las reglas, cualquier elección competida —una tendencia creciente en México- puede generar un conflicto como el que vivió el país en 2006. Tanto la polarización como el estrecho margen de diferencia entre los punteros de la competencia dejaron ver que habían sido generados por reglas con incentivos perversos y desempeños institucionales omisos.

La forma en la que se construyó la elección, tanto en su parte previa de las precampañas como en el periodo de las campañas, dejó ver un doble conflicto. Por una parte, los manejos deficientes de la autoridad electoral frente a problemas importantes, como la actitud de no detener con toda la fuerza legal e institucional la "guerra sucia"; y por la otra, las grandes carencias normativas que tienen las reglas del juego. Para el segundo conflicto pueden darse algunos remedios de sustitución, si se tiene la fuerza de una convicción democrática y no una actitud buro- crática de simple aplicación relativa de la legalidad, como sucedió en diversos casos. En cambio, para el tema del deficiente desempeño institucional no hay remedio normativo, porque se pueden tener todas las ventajas jurídicas y reglas cercanas a la perfección, pero si el desempeño es deficiente, no hay manera de resolver el problema.

Sólo habría que recordar cómo el equipo anterior de consejeros electorales se plantó ante la adversidad en los casos de Pemexgate y Amigos de Fox, y logró sacar adelante los dos proyectos que llevaron a multas históricas para los partidos políticos responsables. En cambio, en 2006, frente a la intervención ilegal de terceros, lo que han declarado para justificar su actitud es que no tenían instrumentos jurídicos suficientes y que el IFE necesita más armas. Está claro que las reglas que tenían a la mano no se emplearon de forma eficiente, así que no todo tiene que ver con las reglas sino, sobre todo, con un desempeño capaz.

De igual forma, el TEPJF, en el último dictamen - $y$ quizá el más importante del grupo de magistrados que estuvo a cargo del organismo entre 1996 y 2006- quedó atrapado en las contradicciones de una elección como la de 2006. De alguna forma, el prestigio del Tribunal construido durante esos años quedó lastimado porque su dictamen del proceso tuvo fallas graves de lógica y de procedimiento jurídico.

En el análisis de los votos en 2006 se ven varios ingredientes de los contornos de un sistema de competencia cuyas tendencias se siguen profundizando; ahora, con el retraimiento del voto tricolor, quedó establecido un país mucho más bipartidista en las elecciones presidenciales, mientras que en los comicios legislativos se conservan las tres grandes fuerzas. El voto diferenciado es una realidad creciente y las migraciones de partido político entre líderes y militantes son cada vez más frecuentes. De forma preocupante, también se pudo observar que hay un foco rojo en materia de participación ciudadana, fenómeno de comportamientos diferentes entre las regiones, pero que deja un suelo firme de insatisfacción y desinterés ciudadano.

La crisis poselectoral representó la confluencia de los errores, omisiones e irresponsabilidades de la clase política. Al mismo tiempo, fue el laboratorio en el cual se 
gestó el regreso de la desconfianza electoral. La diferencia de proyectos de país, junto con el juego sucio, marcaron una preocupante polarización social que tendrá más vida que el mismo proceso electoral.

A pesar de que podemos volver a llegar a promesas no cumplidas en materia de una futura reforma políticoelectoral, podemos insistir por disciplina que mientras no se modifiquen las reglas y los desempeños, no será posible reconstituir los tejidos lastimados y las rupturas que dejó 2006.

En un futuro próximo, los partidos y el gobierno necesitarán cambiar las reglas del juego y también a los operadores, por supuesto; establecer otro mecanismo para su elección y no repetir lo que sucedió en octubre de 2003 con los actuales consejeros. Esa podría ser la vía para que la institución electoral recuperara la confianza de la sociedad y, sobre todo, de la parte agraviada. La recuperación ciudadana del IFE tendría que terminar con la sospecha de que los consejeros responden a intereses partidistas y eso sólo se podrá lograr con un nuevo consejo. Cualquier árbitro que no tiene la confianza de los equipos que disputan una competencia pierde sentido. Sin duda, hay que cambiar el perfil de los consejeros, reducir sus enormes salarios que se han convertido en una retribución desmesurada que pervierte el puesto. La operación electoral también tiene que simplificarse. Modificar los costos, acortar las campañas, transformar el esquema de acceso a los medios masivos, sincronizar los calendarios, como partes claves de una reforma más amplia que modifique el perfil de nuestras instituciones.

¿Qué se puede hacer frente al problema mayor de un sistema político que no resuelve los problemas de una democracia incipiente? Con el modelo electoral mexicano llegamos a la separación radical entre gobernantes y gobernados, partidos que se metieron a la televisión y ciudadanos que sólo escuchan pleitos y promesas. La conclusión general es que México tiene un modelo que nos ha regresado al escenario del conflicto político. La pregunta que queda pendiente para el futuro inmediato es si una nueva composición institucional puede regular y moderar a los actores, a pesar de sí mismos.

Al final, podemos compartir el pesimismo de Pierre Bourdieu, expresado en un post-scriptum a una de sus úl- timos grandes libros, porque retrata bien la mezcla nacional:

El mundo político se cerró poco a poco sobre sí mismo, sobre sus rivalidades internas, sus problemas y sus apuestas. Como los grandes tribunos, los políticos capaces de comprender y expresar las expectativas y reivindicaciones de sus electores son cada vez más raros y distan de situarse en el primer plano de sus formaciones. Los futuros dirigentes se designan en los debates televisivos o los cónclaves de aparato. Los gobernantes están presos de su entorno tranquilizador de jóvenes tecnócratas que a menudo ignoran prácticamente todo lo referente de sus conciudadanos, y a quienes nadie recuerda esa ignorancia (Bourdieu, 1999: 557).

\section{Bibliografía}

Aristegui, Carmen, 2006, Uno de dos. 2006: México en la encrucijada, Grijalbo, México.

Aziz Nassif, Alberto, 2005, "Elecciones, abstención y dinero partidista en México", en Alberto Aziz Nassif y Jorge Alonso Sánchez (coords.), El Estado mexicano: herencias y cambios, t. II: Economía y política, Centro de Investigaciones y Estudios Superiores en Antropología Social, Miguel Ángel Porrúa, México.

Berman, Sabina, 2006, "Felipe Calderón, las tribulaciones de la fe", Letras Libres, núm. 90, junio.

Bourdieu, Pierre, 1999, La miseria del mundo, Fondo de Cultura Económica de Argentina, Akal, Madrid.

Cárdenas, Jaime, 2006, "Absurdos jurídicos del Tribunal Electoral", Eme-equis, 11 de diciembre.

Lijphart, Arend, 2000, Modelos de democracia. Formas de gobierno y resultados en treinta y seis países, Ariel, Barcelona (Col. Ciencia Política).

López Obrador, Andrés Manuel, 2004, Un proyecto alternativo de nación, Grijalbo, México.

Montero, José Ramón e Ignacio Lago, 2005, "La investigación sobre los sistemas electorales: cinco debates y una selección de artículos", Zona Abierta, núms. 110/111, Madrid.

Moreno, Alejandro, 2006, "Ideologías, estilos de vida y votos", Foreign Affairs en español, vol. 6, núm. 2, abril-junio.

Orozco Henríquez, J. Jesús, 2005, Justicia electoral y garantismo jurídico, Miguel Ángel Porrúa, México.

Palma, Esperanza y Roberto Gutiérrez, 2004, El abstencionismo en las elecciones federales de 2003, reporte de investigación, Instituto Federal Electoral, Universidad Autónoma Metropolitana-Azcapotzalco, noviembre. 